\title{
Effects of Metformin in Heart Failure: From Pathophysiological Rationale to Clinical Evidence
}

\author{
Teresa Salvatore $^{1,+}{ }^{\text {, Raffaele Galiero }}{ }^{2,+}{ }^{\mathbb{D}}$, Alfredo Caturano $^{2} \mathbb{D}$, Erica Vetrano ${ }^{2}$, Luca Rinaldi ${ }^{2}$ (D), \\ Francesca Coviello ${ }^{2}$, Anna Di Martino ${ }^{2}$, Gaetana Albanese ${ }^{2}$, Raffaele Marfella ${ }^{2} \mathbb{D}$, Celestino Sardu 2 \\ and Ferdinando Carlo Sasso ${ }^{2, *(D)}$
}

\section{check for}

updates

Citation: Salvatore, T.; Galiero, R.; Caturano, A.; Vetrano, E.; Rinaldi, L.; Coviello, F.; Di Martino, A.; Albanese, G.; Marfella, R.; Sardu, C.; et al. Effects of Metformin in Heart Failure: From Pathophysiological Rationale to Clinical Evidence. Biomolecules 2021, 11, 1834. https://doi.org/10.3390/ biom11121834

Academic Editors: Vera Marisa Costa and Félix Carvalho

Received: 26 October 2021

Accepted: 1 December 2021

Published: 4 December 2021

Publisher's Note: MDPI stays neutral with regard to jurisdictional claims in published maps and institutional affiliations.

Copyright: (c) 2021 by the authors. Licensee MDPI, Basel, Switzerland. This article is an open access article distributed under the terms and conditions of the Creative Commons Attribution (CC BY) license (https:/ / creativecommons.org/licenses/by/ $4.0 /)$.
1 Department of Precision Medicine, University of Campania Luigi Vanvitelli, Via De Crecchio 7, I-80138 Naples, Italy; teresa.salvatore@unicampania.it

2 Department of Advanced Medical and Surgical Sciences, University of Campania Luigi Vanvitelli, Piazza Luigi Miraglia 2, I-80138 Naples, Italy; raffaele.galiero@unicampania.it (R.G.); alfredo.caturano@unicampania.it (A.C.); erica.vetrano@unicampania.it (E.V.); luca.rinaldi@unicampania.it (L.R.); francesca.coviello@studenti.unicampania.it (F.C.); annadimarti@alice.it (A.D.M.); gaetanaalbanese@hotmail.it (G.A.); raffaele.marfella@unicampania.it (R.M.); celestino.sardu@unicampania.it (C.S.)

* Correspondence: ferdinando.sasso@unicampania.it

+ These authors contributed equally to this paper.

Abstract: Type 2 diabetes mellitus (T2DM) is a worldwide major health burden and heart failure (HF) is the most common cardiovascular (CV) complication in affected patients. Therefore, identifying the best pharmacological approach for glycemic control, which is also useful to prevent and ameliorate the prognosis of HF, represents a crucial issue. Currently, the choice is between the new drugs sodium/glucose co-transporter 2 inhibitors that have consistently shown in large CV outcome trials (CVOTs) to reduce the risk of HF-related outcomes in T2DM, and metformin, an old medicament that might end up relegated to the background while exerting interesting protective effects on multiple organs among which include heart failure. When compared with other antihyperglycemic medications, metformin has been demonstrated to be safe and to lower morbidity and mortality for $\mathrm{HF}$, even if these results are difficult to interpret as they emerged mainly from observational studies. Meta-analyses of randomized controlled clinical trials have not produced positive results on the risk or clinical course of HF and sadly, large CV outcome trials are lacking. The point of force of metformin with respect to new diabetic drugs is the amount of data from experimental investigations that, for more than twenty years, still continues to provide mechanistic explanations of the several favorable actions in heart failure such as, the improvement of the myocardial energy metabolic status by modulation of glucose and lipid metabolism, the attenuation of oxidative stress and inflammation, and the inhibition of myocardial cell apoptosis, leading to reduced cardiac remodeling and preserved left ventricular function. In the hope that specific large-scale trials will be carried out to definitively establish the metformin benefit in terms of HF failure outcomes, we reviewed the literature in this field, summarizing the available evidence from experimental and clinical studies reporting on effects in heart metabolism, function, and structure, and the prominent pathophysiological mechanisms involved.

Keywords: type 2 diabetes; metformin; heart failure

\section{Brief History of Metformin and Its Interaction with Cardiovascular Outcomes}

The medicinal properties of metformin (dimethyl biguanide), an antihyperglycemic drug introduced in Europe in 1957 and registered about thirty years later in the US, were already known in the Middle Ages when the French lilac Galega officinalis containing the active compound galegine (isoamylene guanidine), was used to treat people with intense urination $[1,2]$. Today, metformin is the most commonly prescribed medicament for the 
treatment of diabetes, taken by millions of patients worldwide daily, including those with HF [3]. Based on its glucose-lowering effectiveness, safety, favorable effect on body weight, and low cost, metformin is supported by many scientific associations as first-line therapy in patients with T2DM. Above all, indication for use was strengthened based on its assumed favorable and long-lasting benefits on CV morbidity and mortality, best demonstrated by the 10-year follow-up of the landmark UKPDS trial [4,5]. Over time, a huge number of publications have highlighted the CV benefits of metformin, and in 2006, a joint statement of the American Diabetes Association (ADA) and the European Association for the Study of Diabetes recommended this drug as the initial pharmacologic intervention in T2DM [6-8]. Still, nowadays, ADA maintains this position with the recommendation of continuing the drug until tolerated and not contraindicated [9].

Shortly after metformin approval in the US, HF was listed as an absolute contraindication for use since the "phantom" of lactic acidosis, a legacy of previous negative experience with phenformin and buformin, two biguanides abandoned since the 1970s [10]. In the following years, this dictate was largely ignored, also by virtue of the very low risk of lactic acidosis in clinical practice with an estimate of $<10$ cases per 100,000 patient-years [11,12]. At the same time, data were accumulated until conclusive evidence revealed that the benefits of metformin use in diabetic patients with HF outweighed the potential risk [13,14]. With this information, in 2006 the Food and Drug Administration (FDA) removed the absolute HF contraindication, although acute or unstable congestive HF remained in the label's warning section.

The scenario has completely changed since the publication in recent years of a series of CVOTs providing a robust evidence-based CV beneficial effect of glucagon-like peptide-1 receptor agonists (GLP1-RAs) and sodium-glucose co-transporter-2 inhibitors (SGLT2-Is) in diabetic patients at increased risk $[15,16]$. Currently, even in the presence of high CV risk, ADA continues to support metformin as the first-line drug in T2DM, with consideration of concurrent therapy with SGLT2-Is in patients with HF or kidney disease and either SGLT2-Is or GLP1-RAs in patients with predominantly atherosclerotic CV disease (CVD) [9]. Instead, the European Society of Cardiology recommends SGLT2-Is or GLP1-RAs as firstline therapy replacing metformin in patients with target-organ damage or several CV risk factors, and in those with clinically manifest CV comorbid conditions [17]. This guideline discrepancy has raised an intense debate in the medical community.

The arguments for keeping metformin as a cornerstone drug for diabetes even in the presence of a high CV risk are more than one. In the first instance, long-term experience of use, reasonably acceptable side effects, and, more importantly, CV benefits have historically been proven for over twenty years. Ultimately, in all positive CVOTs conducted so far, the newer glucose-lowering agents operated in the background of therapy with metformin that might have influenced the CV outcomes.

The interaction between metformin with SGLT2-Is and GLP1-RAs is a not yet solved issue. A meta-analysis of six CVOTs with four SGLT2-Is by Neuen et al. indicated clear and consistent reductions in CV outcomes, irrespective of the baseline metformin therapy [18] Similar results emerge from a systematic review and meta-analysis of trials with GLP-1 RAs [19]. Instead, in a supplemental analysis of the EMPA-REG OUTCOME trial, the relative risk reduction of CV death in metformin nonusers was $54 \%$ vs. $29 \%$ in metformin users, although with a P interaction of 0.07 [20]. Similarly, the relative risk reduction in the composite of CV death or HF hospitalization in the CANVAS Program was $36 \%$ in metformin nonusers vs. $12 \%$ in metformin users, with a nominally significant $P$ interaction of 0.03 [21]. Because of these results, the suspicion arose that background metformin therapy may obscure the CV benefits of SGLT2-Is, an interpretation that should be done with extreme caution as it is right to do for results from post hoc subgroup analyses [22].

In this review, we aim to support the possible beneficial role of metformin in the management of diabetic patients with established HF and, mainly, its preventive relevance in patients at risk for developing HF, such as those with uncomplicated diabetes, prediabetes, or metabolic syndrome. For this purpose, we synthetized the available evidence 
from experimental and clinical studies reporting on metformin effects in heart metabolism, function, and structure, and the prominent pathophysiological mechanisms involved.

\section{Heart Failure Epidemiology in Diabetes}

Diabetes is a systemic disease characterized by both micro and macrovascular complications, as well as a wide range of extravascular complications, which weigh heavily on both patient health and national health systems [23-26]. HF has emerged as a very common CV complication of diabetes, with a 2.5-fold times higher incidence in diabetic than nondiabetic people, exceeding that of myocardial infarction (MI) or stroke, with a prevalence in diabetic patients aged $\geq 65$ years as high as $22 \%$ [27-30]. As suggested by Lundbæk in 1954 who first introduced the concept of specific DM-related cardiomyopathy, this strict epidemiological relationship depends on the possibility of HF occurrence in T2DM patients even in the absence of other canonical HF risk factors, mainly atherosclerosis and heart ischemic injury. The descriptive terminology of "diabetic cardiomyopathy" is currently used to define myocardial dysfunctions in the presence of diabetes and in the absence of coronary artery disease (CAD), valve heart disease, and other conventional risks for CV diseases (e.g., hypertension, dyslipidemia, and alcoholism) [31]. If diabetes is a well-established risk factor for HF, strong evidence indicates HF as a risk factor for T2DM. Roughly 40 percent of hospitalized patients with HF enrolled in clinical trials suffered from diabetes and among those with HF with reduced ejection fraction (HFrEF) without a known history of diabetes, $25 \%$ had prediabetes, $13 \%$ unrecognized T2DM, and 10\% developed new-onset diabetes during the next four years [32-35]. The relationship between HF with preserved ejection fraction (HFpEF) and diabetes is even closer as T2DM affects about $45 \%$ of affected patients and, when present, the health-related quality of life is worsened and the risk of hospitalization, CV mortality, and all-cause mortality increased [36-38]. Generally, when HF and diabetes coexist, the one condition synergistically and mutually worsens the prognosis of the other. Diabetes or insulin resistance in HF patients reduces the functional capacity, increases the risk of readmission for HF, and doubles the yearly mortality [39-42]. On the other hand, HF represents a very harmful complication of T2DM, since there is a frequent progression to end-stage requiring heart transplantation, and a 3-year mortality of $40 \%, 10$-fold higher than that of non-HF diabetic patients $[43,44]$.

These impressive epidemiological findings emphasize the crucial clinical value of preventing this CV complication.

\section{Activation of AMPK by Metformin}

The AMP-dependent kinase (AMPK) is a serine-threonine protein kinase ubiquitously expressed in nucleated mammalian cells with a crucial role in cellular energy homeostasis. Its malfunction or absence is associated with metabolic disorders, primarily insulin resistance, and could be involved in the pathogenesis of diabetes. It is structurally a heterotrimeric protein complex containing a catalytic $\alpha$ domain and two regulatory $\beta$ and $\gamma$ domains [45]. The increase in intracellular AMP/ATP ratio, such as during strong exercise, hypoxia, or nutritional deficiency, may activate AMPK through phosphorylation of the amino acid threonine (Thr172) on the catalytic $\alpha$ subunit [46]. This is the site predominantly involved in AMPK activation, but several other amino-acid residues can be phosphorylated and determine the same effect [47]. AMP binding to the regulatory $\gamma$ subunit preserves AMPK from dephosphorylation by its three protein phosphatases, 2A, $2 \mathrm{C}$, and $\mathrm{Mg}^{2+} / \mathrm{Mn}^{2+}$-dependent $1 \mathrm{E}$ [48].

Once activated by increased AMP cellular levels signaling a low-energy state, AMPK prompts a switch from ATP-consuming anabolic pathways to ATP-generating catabolic pathways in order to maintain energy homeostasis. The result is an inhibition of the synthesis of triglycerides and proteins, and stimulation of glucose transport, glycolysis, and fatty acid (FA) oxidation $[49,50]$. These effects arise from the phosphorylation of a multitude of downstream effectors involved in the modulation of a myriad of cellular 
processes. In addition to acute regulation of enzymatic activities, AMPK may adaptively reprogram the metabolism through transcriptional changes [50].

The mechanism of metformin action is not completely clarified in humans, but animal and cell culture experiments indicate an activation of AMPK mainly via inhibition of mitochondrial respiratory-chain complex I and increase in the phosphorylated- to unphosphorylated-AMPK ratio [51,52]. For this reason, the drug is classified among the indirect activators of AMPK also taking into account that metformin may block the AMPdeaminase $[53,54]$. In this case too, the result is an increase in the AMP:ATP ratio, which in turn induces AMPK activation. Ultimately, metformin mimics an imbalance between energy supply and use as it happens during fasting and exercise. It is noteworthy that metformin may also directly bind to AMPK subunits determining an increased assembly of the enzymatically active heterotrimeric complex and a greater accessibility for upstream kinases [55,56] (Figure 1).
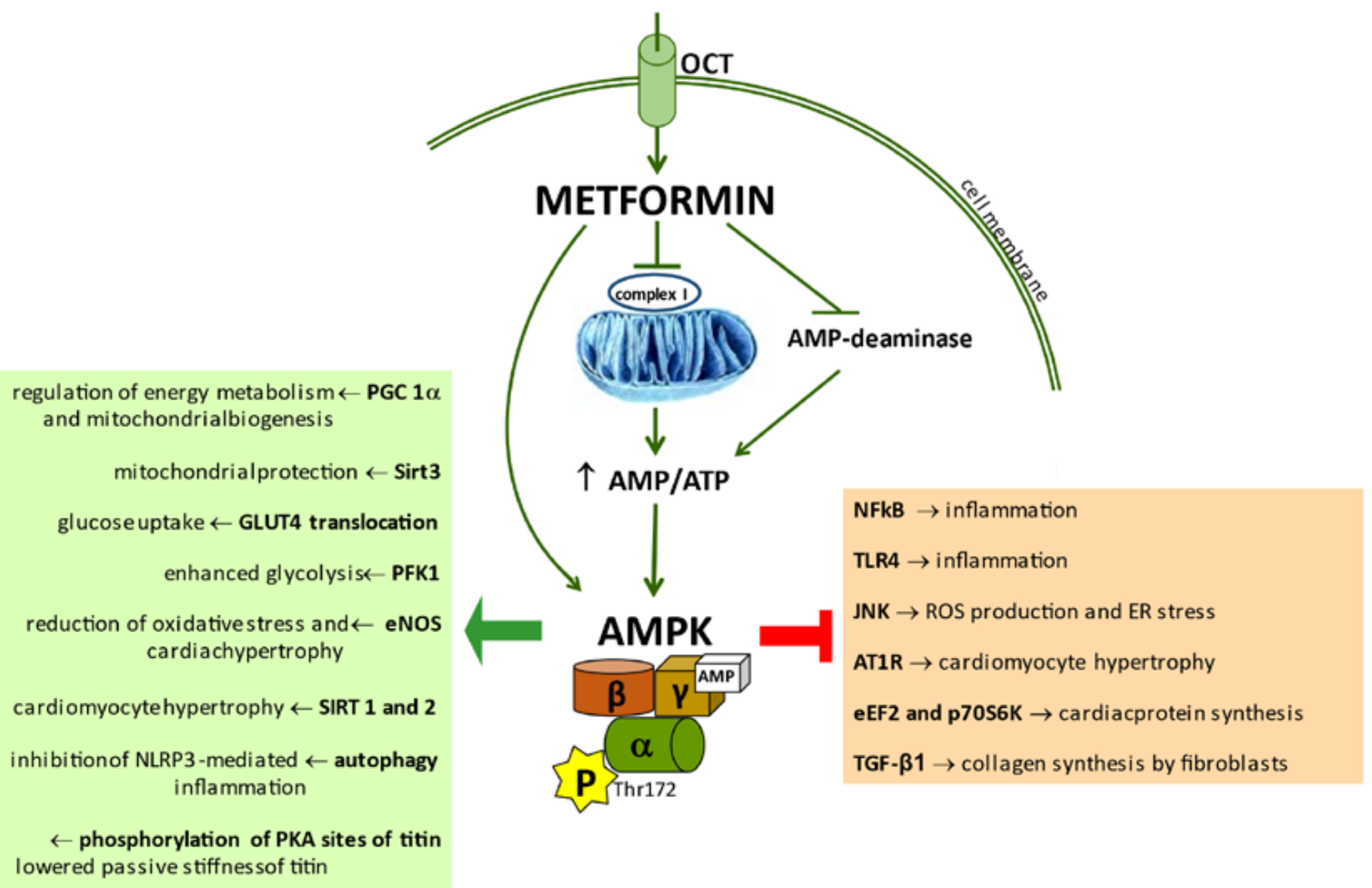

Figure 1. Activation of AMPK by metformin and its principal downstream pathways involved in HF physiopathology. AMPK: AMP-dependent kinase; AT1R: AngII type 1 receptor; eNOS: endothelial nitric oxide synthase; eEF2: eukariotic elongation factor-2 kinase; GLUT4: glucose transporter protein type-4; JNK: c-Jun N-terminal kinase; NF-kB: nuclear factor-kB; OCT: organic cation transporter; p70S6K: protein kinase 70S6; PFK1: phosphofructokinase 1; PGC1 $\alpha$ : peroxisome proliferator-activated receptor-g coactivator-1 $\alpha$; PKA: protein kinase A; SIRT1-2-3: deacetylase Sirtuin 1-2-3; TGF$\beta$ : transforming growth factor- $\beta$; TLR4: Toll-like receptor 4 .

\section{Mechanisms of Beneficial Impact of Metformin on Heart Failure}

The current knowledge supports a protective role of metformin against HF based on a series of complex and multidirectional pleiotropic actions. On the one hand, the biguanide may prevent systemic and coronary atherosclerosis by correcting multiple $\mathrm{CV}$ risk factors and reducing endothelial dysfunction, oxidative stress, and inflammation. In addition, it may mediate direct positive functional and structural effects preserving LV morphology and the systo-diastolic performance of the heart (Figure 2) [7,57]. 


\section{PROTECTION AGAINST HEART FAILURE BY METFORMIN}

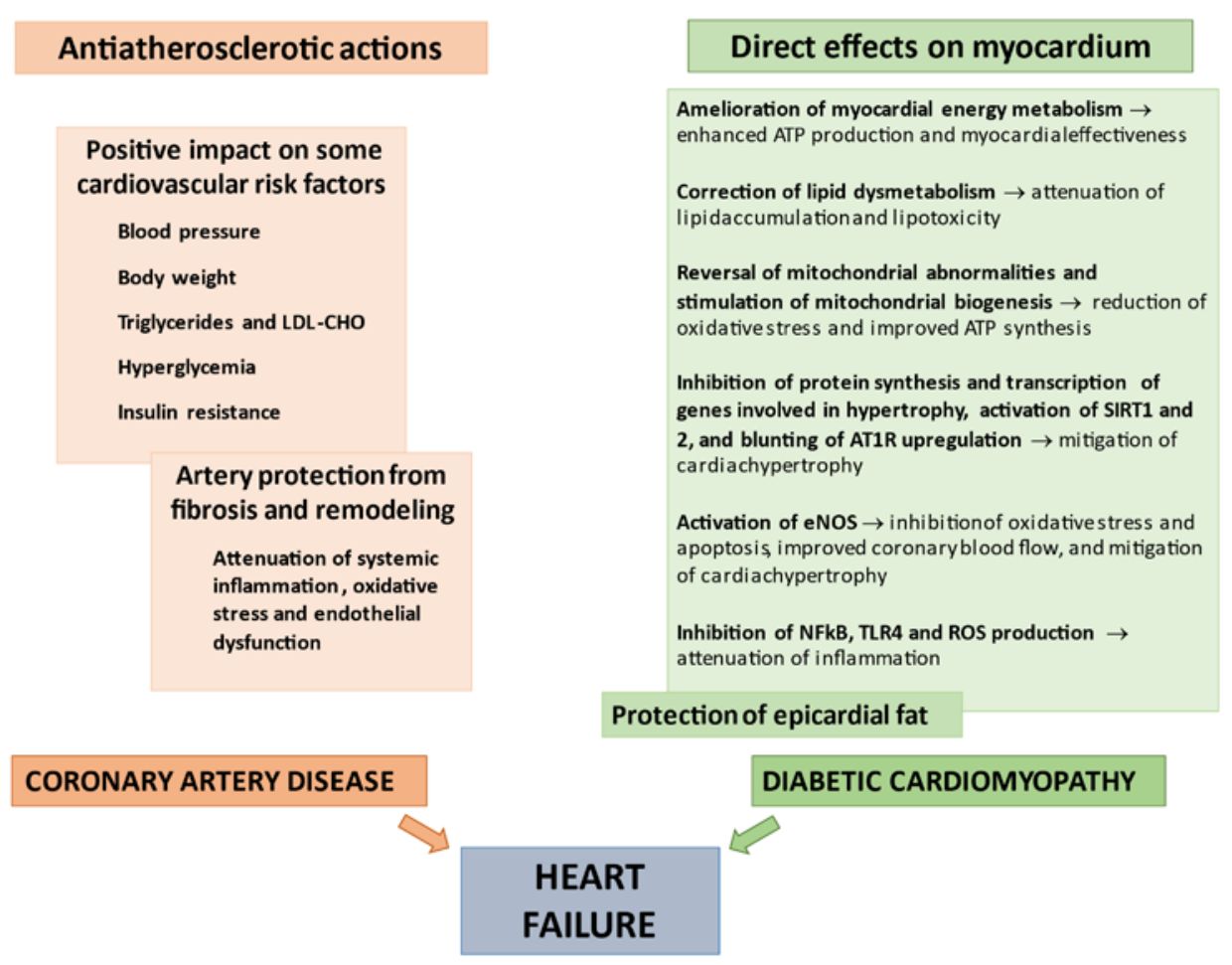

Figure 2. Anti-atherosclerotic actions and direct myocardial protective effects of metformin against HF. AT1R: AngII type 1 receptor; eNOS: endothelial nitric oxide synthase; LDL-CHO: low-density lipoprotein cholesterol; NF-kB: nuclear factor-kB; ROS: reactive oxygen species; SIRT1: deacetylase Sirtuin1; TLR4: Toll-like receptor 4 .

\subsection{Correction of CV Risk Factors}

Metformin may positively influence the development and progression of atherosclerotic disease, and therefore of CAD-related HF, in people with or without T2DM, including subjects with type 1 diabetes [58]. Merely, the drug is able to correct some atherosclerotic risk factors. Blood pressure was lowered in salt-induced hypertension of spontaneously hypertensive rats and in non-diabetic patients, specifically those with impaired glucose tolerance or obesity $[59,60]$. As reported in HF patients who lost weight, metformin causes a decrease in food intake to $300 \mathrm{kcal} /$ day and a loss in body weight that results in improvement of insulin sensitivity, attenuation of inflammation, and a series of beneficial changes in stroke volume, cardiac output, and myocardial oxygen consumption $\left(\mathrm{MVO}_{2}\right)[61,62]$. A decrease in blood levels of triglycerides and LDL cholesterol may contribute to atheromatosis prevention [63].

Regarding hyperglycemia, a beneficial impact of glycemic control on CV outcomes is reported during acute coronary syndrome [64-66]. Instead, clinical trials targeting more intensive glucose-lowering therapy obtained benefits only in long-term follow-ups such as UKPDS, but were not helpful if introduced late in the course of T2DM as demonstrated by three major trials (ACCORD, ADVANCE, and VA-DT) [67-70].

Likely, the main atheroprotection depends on insulin-sparing and sensitizing action of metformin that is able to correct the generalized insulin resistance inherent in obesity and T2DM, and the associated systemic dysmetabolic milieu with low-grade inflammation and oxidative stress. The resulting beneficial effects on the arterial wall, both on endothelial and smooth muscle cells, may protect vasculature from fibrosis and remodeling [71-74]. 


\subsection{Direct Beneficial Actions of Metformin on Myocardium}

The heart expresses the organic cation transporters OCT1 and OCT3, which are able to control the cellular uptake of metformin, and compelling experimental evidence documents direct effects of metformin on both isolated cardiomyocytes and the beating heart (Figure 1) [75].

Metformin has been proven to stimulate multiple cardioprotective pathways, mainly implemented by the activation of AMPK, whose subunits in the myocardium display two different isoforms, the $\alpha 1$ subunit mostly expressed in cardiac endothelial cells and the $\alpha 2$ subunits in cardiomyocytes [48,76]. At the heart level, AMPK may phosphorylate a plethora of metabolic enzymes, transporters of metabolites, and signaling molecules, involved in the regulation of energy metabolism, protein synthesis, mitochondrial health, autophagy, oxidative stress, inflammation, and so on $[57,77,78]$. As proofs, metforminrelated improvements in myocardial structure and function are not seen in AMPK-deficient mice and as indicated by a limited metanalysis of five studies, the myocardiocyte levels of phosphorylated AMPK from metformin-treated animals were almost double compared to controls (Figure 3) [78,79].

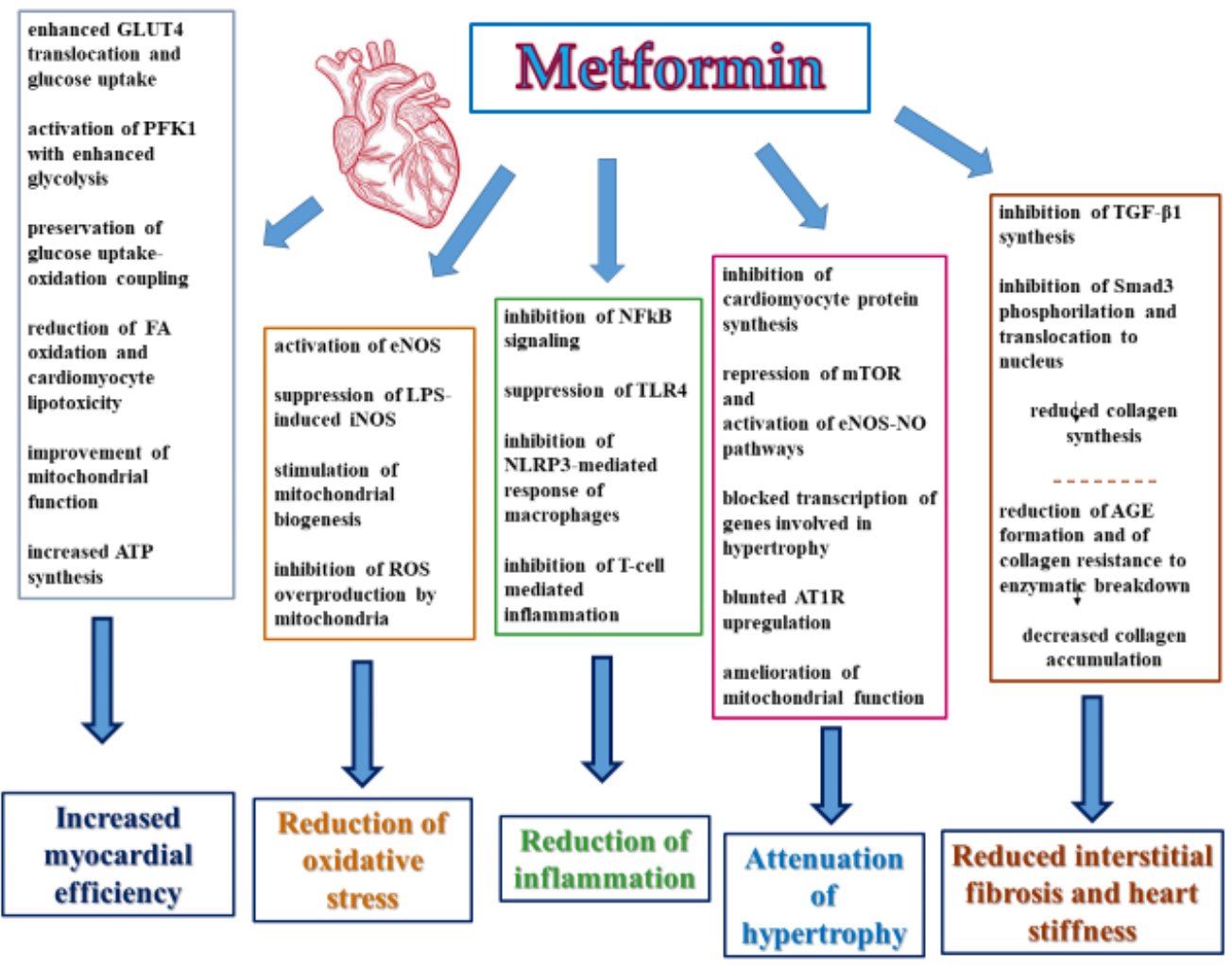

\section{Amelioration of systolic and diastolic function}

Figure 3. Main mechanisms of cardio-protection by metformin in failing heart (data from preclinical studies). AGE: advanced glycation endproducts; AT1R: AngII type 1 receptor; eNOS: endothelial nitric oxide synthase; FA: fatty acid; GLUT4: glucose transporter protein type-4; iNOS: inducible nitric oxide synthase; LPS: lipopolysaccharide; mTOR: mechanistic target of rapamycin; NF-kB: nuclear factor-kB; NO: nitric oxide; PFK1 phosphofructokinase 1 ; ROS: reactive oxygen species; TGF- $\beta 1$ : transforming growth factor $\beta 1$; TLR4: Toll-like receptor 4 .

\subsubsection{Effects on Myocardial Energy Metabolism and Efficiency}

Although the cardiomyocytes of a healthy heart can flexibly use different substrates depending on availability and energy requirements, they prefer FA oxidation to fuel the high rate of ATP production needed for the continuous heart mechanical work, so much 
that $70-90 \%$ of necessary myocardial energy supplied by this source $[80,81]$. Instead, profound changes in cardiac energy metabolism take place during the usually long and complex evolution of HF, with a progressive decline in FA utilization and an initial upregulation and subsequent reduction of glucose utilization [82]. The reduction in ATP production represents a constant feature of heart failure [83].

By activating AMPK, metformin induces a series of cardiomyocyte responses that ameliorate glucose utilization, mitochondrial respiration, and ATP synthesis resulting in a better systolic and diastolic effectiveness $[79,84,85]$. The main AMPK downstream mediators of these responses are the eNOS and the peroxisome proliferator-activated receptor-g coactivator-(PGC) $1 \alpha$, a crucial regulator of cellular energy substrate metabolism $[57,79]$.

It has been observed that the AMPK activation induced by metformin enhanced translocation of membrane GLUT4 and glucose uptake in insulin-resistant cardiomyocytes [86,87]. Moreover, in hypertrophied rat heart metformin intensified the glycolysis by activating the rate-limiting phosphofructokinase 1 (PFK1) [88].

Metformin treatment in vivo or added to the perfusate of ex vivo rat hearts subjected to a highly increased workload prevented the AMPK down-regulation and, preserving the glucose uptake-oxidation coupling, avoided the detrimental intracellular accumulation of glucose 6-phosphate. This latter has been found to be responsible for downstream activation of mammalian target of rapamycin (mTOR) and consequent endoplasmic reticulum stress (ER) and contractile dysfunction [89].

The insulin resistance peculiar to HF impairs the metabolic adaptability of the myocardium, leading to an unbalanced lipid and glucose uptake that favors lipid accumulation and lipotoxicity in cardiomyocytes [90]. The protective effects of metformin on cardiac lipid dysmetabolism were investigated in prediabetic rats affected by hereditary hypertriglyceridemia, a model characterized by ectopic lipid deposition including the heart. A reduction of myocardial stearoyl-CoA desaturase, a key lipogenic enzyme, and increased glucose and decreased FA oxidation in the heart were observed after metformin treatment [91]. Concomitantly, the accumulation of the lipotoxic intermediate diacylglycerols and lysophosphatidylcholine was attenuated. A human study observed a decreased cardiomyocyte accumulation of lipids associated with a myocardial reduction of insulin resistance markers (IRS-1 and IRS-2) and lipogenic factors (PPAR- $\alpha$ and SREBP-1c) in healthy hearts transplanted in T2DM recipients chronically treated with metformin [92].

Experimental evidence proves that a lower ATP synthesis with a reduced energy conversion in mechanical work directly impairs contractile function, thus representing the main culprits of heart failure [83]. In this landscape, mitochondria have a leading role as suggested by the degenerative changes in cardiomyocytes collected from HF patients, and the association between mitochondrial abnormalities and severity of LV dysfunction observed in a canine model of HF [93-95]. In addition, cardiomyocyte mitochondrial activity is closely coupled to MVO2 as oxidative phosphorylation meets $95 \%$ of cardiac cellular energy demand [93]. Hence, drugs specifically able to influence cardiomyocyte energetics operating in mitochondria as metformin, so-called mitotropes, provide an attractive tool to improve cardiac performance in HF [96].

Experimental and clinical studies show that metformin may successfully reverse mitochondrial abnormalities in cardiomyocytes, improving mitochondrial respiration and ATP synthesis, lessening mitochondrial respiratory uncoupling and myocardial $\mathrm{MVO}_{2}$, and increasing myocardial efficiency [84,97]. In a mice model of HF after myocardial infarction, metformin improved cardiac systolic function, reduced apoptosis of myocardial cells, and improved mitochondrial function. All effects were associated with up-regulation in myocardial tissue of deacetylase Sirtuin 3 (SIRT3) and activation of PGC- $1 \alpha$, two factors closely related to mitochondrial energy metabolism as already reported in previous studies $[84,98,99]$.

In a recent randomized controlled trial (RCT) using PET and transthoracic echocardiography, a 3-month treatment with metformin added to optimal medical HF regimen in 36 non-diabetic patients with symptomatic EFrHF, determined a $17 \%$ reduction of $\mathrm{MVO}_{2}$ 
and a $20 \%$ increase in myocardial efficiency expressed as work metabolic index [97]. This energy-sparing effect was achieved in addition to $\beta$-blocker therapy, which may increase efficiency by $39 \%$ and reduce $\mathrm{MVO}_{2}$ by $24 \%$ [100]. Overall, by ameliorating glucose metabolism, mitochondrial function, and ATP production, and by attenuating lipotoxicity in cardiomyocytes, metformin is able to improve systolic and diastolic effectiveness.

\subsubsection{Myocardial Anti-Oxidative and Anti-Inflammatory Effects}

Oxidative stress represents one of the most significant insults disrupting cardiomyocyte homeostasis in failing myocardium that can be effectively counteracted by metformin through an increase of NO synthesis, amelioration of mitochondrial function, and other mechanisms [101].

The heart expresses three isoforms of NO synthase, endothelial NOS (eNOS) expressed in endothelial cells but also in the cytoplasm of cardiomyocytes and neuronal (nNOS) and inducible NOS (iNOS), both mainly located in cardiomyocytes [85]. The nanomolar amounts of NO generated by eNOS and nNOS play a beneficial physiological role. Differently, iNOS produces NO in micromolar concentration, namely an excess of NO that impairing myocardial contractility may be deleterious for diastolic and systolic LV function [102,103]. In detail, excessively high cellular NO level activates, via the second messenger cGMP, both the protein kinase G that blocks the L-type calcium channels and consequently decreases the calcium influx into cells, and the cGMP-activated phosphodiesterase that breaks down the cAMP [103].

Metformin activates eNOS via the AMPK-dependent phosphorylation and association with heat shock protein-9 [104]. The increase in local generation of NO leads to inhibition of oxidative stress and apoptosis together with vasodilation, and thereby improves coronary blood flow, afterload, and LV function [105-107]. In addition, studies in vitro demonstrated that whereas IL-1 beta induces the cardiomyocytes mRNA expression of iNOS and its de novo synthesis leading to an excess of NO local production, metformin is able to suppress the lipopolysaccharide (LPS)-induced iNOS and NO production in monocytes [108,109].

Considering mitochondria as the primary energy-generating organelles but also, if dysfunctional, the main source of reactive oxygen species (ROS), the other barrier implemented by metformin against oxidative stress is the stimulation of mitochondrial biogenesis [110]. In a recent study on $\mathrm{H} 9 \mathrm{C} 2$ cardiomyocytes, metformin exerted protective effects against high glucose-induced oxidative stress by activating AMPK and enhancing the expression of transcription factors related to mitochondrial biogenesis (PGC- $1 \alpha$, nuclear respiratory factor-1, and -2) and of mitochondrial genes such as NDUFA13, an indispensable assembly factor of complex 1, and manganese-dependent superoxide dismutase [111].

Previous observations report that exogenous ROS administration to H9c2 cardiomyoblasts stimulated the c-Jun N-terminal kinase (JNK), a well-known member of MAPKs [112]. In experiments in $\mathrm{H} 9 \mathrm{c} 2$ cardiomyocytes, metformin administration inhibited the mitochondrial overproduction of ROS induced by high glucose plus hypoxia/re-oxygenation injury, via signaling mechanisms involving activation of AMPK and concomitant inhibition of JNK expression [113]. Concurrently, metformin mitigated the associated inflammatory response evidenced by the significant increase in mRNA of pro-inflammatory cytokines (TNF- $\alpha$, IL- $1 \alpha$, and IL-6) [113].

Oxidative stress has been implicated in the activation of endoplasmic reticulum (ER) stress, a promoter of cellular autophagy and apoptosis in the diabetic heart [114]. The activation of AMPK using metformin may decrease the ER stress-induced cell death [115].

Closely linked to oxidative stress, inflammation is considered a driving mechanism in the pathophysiology of HF that may also be controlled by metformin, a drug with largely proven flogosis-inhibitory effects, independently of its blood glucose-lowering action and with therapeutic potential in clinical conditions other than T2DM [116-119]. Actually, the use of metformin is significantly associated with reduced circulating levels of inflammatory markers and cytokines in diabetic as well as in non-diabetic people with HF, indeed in COVID-19 diabetic patients [120]. 
Since a main mechanism linking oxidative stress to tissue injury is the ROS-stimulated inflammatory response, the anti-oxidative properties of metformin may per se attenuate inflammation. In addition, metformin seems to exert a direct anti-inflammatory action by inhibiting the nuclear factor kB (NF-kB) signaling through AMPK-dependent and independent pathways [121,122].

The modulation of the local inflammatory response triggered by MI is crucial to protect the infarcted cardiac tissue and to prevent HF development. Acute administration of metformin in isoproterenol-induced MI in rats may halt the inflammatory responses and inhibit the MI-associated LV dysfunction through the activation of AMPK and subsequent suppression of Toll-like receptor 4 (TLR4), a factor that activates the expression of several pro-inflammatory cytokine genes [123]. Similarly, an inhibitory effect on TLR4 signaling with reduced post-MI cardiac dysfunction was induced by chronic pretreatment with a low dose of metformin [124]. Of relevance, studies have demonstrated a pivotal role of TLR4 even in myocarditis and HF [125].

A recent study investigating the inflammatory response during MI demonstrated that metformin could activate autophagy and subsequently inhibit the NLRP3-mediated pro-inflammatory response of myocardial macrophages [126]. The same effects on the autophagy-NLRP3 axis mediated the anti-inflammatory and cardioprotective response to metformin observed in high glucose-treated cardiomyocytes and in diabetic mice [127]. These results are in line with previous experiments on diabetic OVE26 mice indicating that through the AMPK signaling pathway, metformin administered for 4 months could upregulate autophagy activity and prevent cardiomyopathy [128].

The role of a dysfunctional T-cell-mediated immune response in the onset and progression of CV disease is well documented and increasing evidence supports inhibition of T-cell-mediated inflammation by metformin [129]. Overall, in vitro and in vivo studies in animal models of chronic inflammation indicate that metformin exerts its anti-inflammatory effect through an AMPK-dependent modulation of the mTOR and the signal transducer and activator of transcription (STAT) 3 and 5 of T-cells [130].

Overall, several studies show the positive effects of metformin on oxidative stress and inflammation, two crucial processes strongly interconnected by a reciprocal worsening that threaten heart health both systemically and locally. In the last years, it has been reported that metformin may protect epicardial adipose tissue, a structure closely interconnected to the myocardium through a shared microcirculation that when enlarged takes on a harmful secretory profile of adipokines, which can damage the heart through inflammatory mechanisms [131,132]. It is believed that this benefit mainly involves HFpEF [133].

\subsubsection{Prevention of Remodeling}

Metformin shows potent anti-remodeling properties linked to attenuation of myocardial hypertrophy and fibrosis that may preserve LV morphology and systo-diastolic performance, irrespective of glycemic status and the nature of myocardial insults. These beneficial actions have been well demonstrated in a pacing-induced HF model in dogs and in murine models of ischemia-induced cardiac injury or spontaneously hypertensive, insulin-resistant state. In these experimental models, AMPK activation by metformin repressed cardiac remodeling and rescued cardiac function $[79,106,134]$.

Mammalian cardiomyocytes lose the ability to proliferate after birth; thus their growth is the only mechanism that may enlarge cardiac mass to increase the contractile function and reduce ventricular wall stress in response to a workload excess [135-137]. The development of cardiac hypertrophy is associated with metabolic reprogramming increasing protein synthesis and strongly involving AMPK $[136,138]$. In hearts from AMPK- $\alpha 2$ knockout mice, hypertrophy induced by phenylephrine is greatly accentuated, and human mutations in the AMPK $\gamma$ subunit cause familial hypertrophic cardiomyopathy $[139,140]$. On the contrary, AMPK activation can inhibit some molecular mechanisms promoting cardiomyocyte cell growth such as mTOR [141]. In vitro studies confirm that pharmacological activation of AMPK by metformin can inhibit two pathways involved in heart regulation of protein 
synthesis, the eukaryotic elongation factor 2 (eEF2) and the p70 ribosomal S6 protein kinase (p70S6K) [142].

Metformin mitigated cardiac hypertrophy in mice subjected to chronic pressure overload, through an AMPK-mediated activation of the eNOS-NO downstream signaling pathway [143].

In AngII-induced hypertrophy of cultured cardiomyocytes, metformin exerted antihypertrophic effects associated with AMPK-induced blunting of AngII type 1 receptor (AT1R) up-regulation and of mitochondrial dysfunction through the SIRT1/eNOS/p53 pathway [144]. This effect is in accord with the results of a rodent study in which SIRT2 repressed the aging-related and AngII-induced cardiac hypertrophy, whereas the loss of SIRT2 expression blunted this protection against cardiac hypertrophy, an effect likely caused by the failure to activate the liver kinase B1-AMPK pathway [145]. Similarly, experimental models demonstrated that the activation of SIRT1 along with PGC-1 $\alpha$ and AMPK, and the suppression of mTORC1 along with its upstream regulator Akt, exerted cardioprotective effects by promoting survival of cardiomyocytes over their growth [146].

Another study demonstrated that aldolase A was hyper-expressed in a mouse model of cardiac hypertrophy and that activating AMPK by metformin or AICAR this overexpression as well as the cardiomyocyte hypertrophy were prevented [147].

Other evidence supports those anti-hypertrophic actions of metformin not mediated by AMPK activation. Repressing mTOR signaling, metformin was able to protect mouse hearts against ventricular hypertrophy and dysfunction in both wild-type and AMPK $\alpha 2$ knockout mice exposed to transverse aortic constriction-induced hypertrophy [148]. Using primary cultured cardiomyocytes, a recent study demonstrated that metformin could halt the transcription of genes involved in hypertrophy response, such as endogenous atrial natriuretic factor and brain natriuretic peptide genes [149]. In a previous study, metformin suppressed the acetylation of histone H3K9 by inhibiting the histone acetyltransferase activity of p300 that has been involved in the development of HF [150].

In humans, a trial enrolling few patients (MET-REMODEL) documented a reduction in LV mass indexed to height in 68 dysglycemic not diabetic patients with CAD treated with metformin over a 12-month follow-up [151].

The other deleterious player of heart remodeling is the interstitial accumulation of collagen, an important promoter of increased stiffness, and impaired heart muscle relaxation.

Sasaki et al. demonstrated that metformin reduced myocardial fibrosis and improved cardiac performance through suppressing mRNA expression of the transforming growth factor (TGF)- $\beta 1$ [134]. Another study in mice subjected to transverse aortic constriction demonstrated that metformin could modulate the expression of extracellular matrix protein genes. In this model, biguanide inhibited the TGF- $\beta 1$ synthesis induced by pressure overload and the phosphorylation of Smad3 factor and its TGF- $\beta 1$-stimulated translocation to the nucleus, leading to impaired collagen synthesis in cardiac fibroblasts [152]. Metformin determined an AMPK-mediated reduction in the expression of TGF- $\beta 1$, basic fibroblast growth factor, and TNF- $\alpha$ in primary cardiomyocytes [153]. In accordance, a reduced post-MI scar formation occurred in AMPK $\alpha 1$ knockout mice suggesting the centrality of this kinase in cardiac fibroblast/myofibroblast biology [154].

In a study examining the angiotensin (Ang) II-induced differentiation of cardiac fibroblasts into myofibroblasts, a critical event in the progression of cardiac fibrosis and pathological cardiac remodeling, metformin decreased the Ang II-induced ROS generation in cardiac fibroblasts by inhibiting the activation of the protein kinase C-NADPH oxidase pathway [155].

As largely documented, metformin may directly impact myocardial hypertrophy and interstitial fibrosis, the two structural hallmarks in the physiopathology of HF. In addition, the reduced production of advanced glycation end products (AGE) by biguanide may contribute. AGEs are reported to induce crosslinks within and between the long-living protein collagen, thus increasing its resistance to enzymatic breakdown that leads to a permanent interstitial accumulation $[28,156,157]$. Interestingly, metformin may correct 
the significant increase of cardiomyocyte apoptosis and death characterizing the heart of diabetic patients and representing the primum movens for hypertrophic and fibrotic LV remodeling [31,158]. Furthermore, it is reported that the AMPK activation by biguanide prevented the apoptosis of cardiomyocytes during their incubation with $\mathrm{H}_{2} \mathrm{O}_{2}$ and reduced the number of dead cardiomyocytes in the hearts of dogs with experimental HF [134]. Other experiments confirmed this effect in the setting of chronic myocardial ischemia [159].

\subsubsection{Amelioration of Left Ventricle Function}

Several preclinical studies document positive effects of metformin on cardiac performance, as in a genetic model of spontaneously hypertensive insulin-resistant rats, in rodent models of volume-overload HF with streptozotocin diabetes, in dogs with pacinginduced $\mathrm{HF}$, and in the setting of post-ischemic HF after permanent left coronary artery occlusion [79,106,134,157,160-163]. In a rodent model of HFpEF, chronic treatment with metformin reduced the elevation in right ventricular pressure and the extent of pulmonary small artery hypertrophy [164]. In a brief meta-analysis of six studies in various experimental models of HF, metformin therapy was associated with an $8 \%$ higher LVEF than other antidiabetic drugs [78]. A mechanism possibly justifying these results may be the enhanced phosphorylation of the phosphokinase A sites in the N2B spring element of titin induced by metformin in a mouse model with an HFpEF-like phenotype [165]. This change may lower the cardiomyocyte stiffness, a typical finding of myocardial biopsies from patients with HFpEF, in association with cardiomyocyte hypertrophy and interstitial fibrosis [166].

On the contrary, the results of clinical studies are somewhat conflicting. In two studies in diabetic subjects, metformin predicted LV dysfunction. This result is questionable as treated patients were more obese than controls $[167,168]$. Instead, other investigations documented benefits on diastolic and systo-diastolic function, except in a study on advanced HFrEF [169-171]. Moreover, long-lasting metformin therapy was beneficial for improving diastolic function and delaying the progression of HFpEF in hypertensive diabetic people [172]. The results of the few and small placebo-controlled RCTs evaluating metformin in the setting of HF are rather disappointing. A 3-4 month therapy in HFrEF patients with prediabetes or insulin resistance does not improve resting LVEF and global longitudinal strain, nor exercise capacity [97,173]. In the GIPS-III trial, a prospective study evaluating the effect of 4 months of metformin treatment in 380 non-diabetic patients presenting STEMI and a mean LVEF of 54\%, the LVEF and the diastolic function was not affected at the end of therapy, and not even 2 years later [174-176]. Evidence from the nine RCTs included in a recent systematic review only supports a metformin beneficial effect in improving MVO2 and reducing NT-proBNP levels in insulin-resistant or T2DM patients with HF, especially those without overt signs of CVD [177]. Instead, in a recent trial enrolling 54 non-diabetic patients with metabolic syndrome, metformin treatment on top of lifestyle counseling ameliorated diastolic dysfunction [178].

Overall, an amelioration of cardiac functional parameters by metformin may be more likely expected in patients with mild forms of HF, mainly HFpEF, no history of CV events, and after a long time chronic treatment.

\section{Effects of Metformin on Adverse Consequences of HF in Clinical Studies}

Overall, a huge number of studies on small or large populations reported a beneficial impact of metformin therapy on HF prognosis.

\subsection{Effects on Total and HF Mortality}

Several authors described the reduction of HF mortality compared to sulfonylureas, glucose-lowering regimens other than metformin, or lifestyle modification alone, as well as of all-cause mortality compared to sulfonylureas or not-metformin monotherapy [14,179-187]. Treatment with metformin determined an $18 \%$ lower risk of death in elderly patients discharged with diabetes and HF [13]. A significant reduction of mortality was obtained even in diabetic patients with incident HF who were metformin new users or already receiving 
oral antidiabetic agents, as well as in subjects with both newly diagnosed HF and diabetes, with respect to patients not exposed to any antidiabetic drug [14,177,182,188].

Meta-analyses of observational studies or RCTs confirm positive outcome results, such as improved survival with metformin monotherapy, lower $\mathrm{CV}$ mortality vs. sulfonylureas, and reduced all-cause mortality in metformin-treated diabetic patients [189-191]. In a recent meta-analysis including 40 studies comprising over a million diabetic patients, metformin reduced all-cause mortality as well as the incidence of $\mathrm{CV}$ events in people with $\mathrm{HF}$ and CHD better than sulfonylureas or non-medication [192].

In HFpEF patients, metformin reduced long-term mortality following admission for acute HF and all-cause mortality in subjects with poor glycemic control [193,194]. A recent systematic review and meta-regression analysis confirmed a significant reduction of mortality in HFpEF by metformin, even after adjustment for HF therapies including $\beta$-blockers and angiotensin II inhibitor ACE-Is [195].

Instead, in a cohort study involving diabetic patients with advanced HF (III and IV NYHA class), one-year survival in metformin-treated and non-metformin-treated patients was $91 \%$ and $76 \%$ respectively, a result not statistically significant after multivariate adjustment [171].

The lowering of mortality risk by metformin seems to be lower than ACE-I/ARB but greater than $\beta$-blockers and detectable even in diabetic patients usually excluded from clinical trials due to the presence of several comorbidities, such as renal insufficiency, MI, and obesity [182,184]. Accordingly, in a systematic review of observational studies, metformin treatment was associated with a mortality of $23 \%$ compared to $37 \%$ in controls (mostly on sulfonylurea therapy), across different classes of kidney dysfunction and EF $[196,197]$.

Only a few meta-analyses documented a null effect of metformin on all-cause and CV mortality and on the risk of HF [107-109]. Others reported a troubling increased risk of death with the concomitant use of metformin and SU [189-192,198-201].

Interestingly, a significantly lower in-hospital mortality emerged in metformin-user diabetic patients with COVID-19 [202-204].

\subsection{Risk of Admission for HF}

Metformin reduced the risk of admission for HF compared to thiazolidinediones, sulfonylureas, or other non-metformin contemporary regimens, and once again versus sulfonylureas in T2DM patients who persisted in the use of biguanide despite reduced kidney function $[13,14,181,198,205]$. This benefit was confirmed by systematic reviews and meta-analyses [189-191,196].

In a retrospective observational study, the benefits of metformin in reducing HF exacerbations dissipated after a few days of non-use, and the cumulative drug exposure did not decrease the risk of HF-related exacerbation [206]. Otherwise, in another study metformin was associated with a lower risk of hospitalization for HF in a dose-response pattern with a beneficial effect especially significant when used for more than 2.5 years [207].

\subsection{Risk of New-Onset HF}

In some studies, chronic treatment with metformin linked with a lower risk of newonset HF [208,209]. McAlister et al. estimated that 4.4 cases of HF per 100 treatment-years developed in patients using sulfonylurea monotherapy versus 3.3 cases per 100 years in those using metformin monotherapy [210]. Examining 232 meta-analyses evaluating ten classes of diabetes drugs, metformin appeared neutral with regard to all CV outcomes, but it might decrease the risk of major adverse $\mathrm{CV}$ events, comprising HF, compared with placebo or no treatment [211].

Although with the well-known limitations of observational studies and meta-analyses but considering the advantage of a huge amount of data, these studies collectively emphasize the benefits of metformin in HF outcomes and confirm its better effectiveness in the first stages of $\mathrm{EF}$, particularly $\mathrm{HFpEF}$, as emerged in preclinical studies. 


\section{Concluding Remarks and Future Perspectives}

Today, a large number of people suffer from concomitant diabetes and HF and there will be even more in near future. It is therefore a relevant focus to identify the best pharmacological approach for glycemic control, also useful to both prevent and manage this CV complication in diabetic people.

Metformin is the current first choice for the great majority of patients with newly diagnosed T2DM requiring medical therapy. Based on the literature, the data suggest the ability of metformin to avert the development and/or progression of HF. This early inclusion in a therapeutic protocol of diabetes is a great opportunity to implement a preventive strategy against HF, such an advantage is not documented for other antihyperglycemic drugs, comprising the newer ones. For instance, the CVOTs randomized to SGLT2 inhibitors showing $\mathrm{CV}$ benefits included patients generally with advanced diabetes and a great burden of CVD. Only a recent observational study evaluating the SGLT2-I effectiveness compared to metformin for reducing CV events in T2DM patients, treatment-naïve in the preceding year, registered after a short-/mid-term follow-up of approximately 600 days an $18 \%$ reduction in CV events including IMA, HF, and stroke. However, the wide $95 \%$ CIs of many outcomes precluded a definitive conclusion on an eventual greater CV benefit for gliflozins [212].

As regards the management of established HF, choosing to treat diabetic patients with metformin is a sensitive matter given the robust data from CVOTs published since 2015 providing compelling benefits for new classes of antihyperglycemic agents. However, these studies had as comparator group an active medicament and not placebo. Moreover, the high prevalence of baseline metformin use in these trials may corroborate a role for biguanide as first-line therapy for T2DM with high CV risk.

Unfortunately, after over 60 years of clinical use and apart from the UKPDS, no large trial has specifically assessed the impact of metformin therapy on risk for HF development or on the prognosis of established HF among patients with T2DM. Nor do we have comparison data with SGLT2-Is apart from those that had as a primary outcome the change in $\mathrm{HbA1c}$ [213]. This gap is not proof that advantages do not exist for metformin. Moreover, we cannot ignore the deep experience with its use in clinical practice and the long-term evidence, lasting almost two decades, from a great harvest of data from experimental investigations providing mechanistic explanations that incessantly continue to emerge in the literature. Otherwise, the information on the long-term CV outcomes of SGLT2-Is and GLP1-RAs are lacking, and mechanistic studies are quite scarce since the objective difficulty for new medications is to equalize the extraordinary endurance for well over half a century of metformin.

To date, we know that, at a minimum, metformin is not harmful to diabetics with concurrent $\mathrm{HF}$ and that it may even be beneficial in reducing CV mortality and morbidity, in addition to the not negligible potential role in the prevention of aging-related diseases as well as cancer [214-217].

To dispel any doubt and make complete clarity on the metformin efficacy in HF diabetic patients, large long-term clinical trials powered to assess CV protection would be needed. This project is extremely difficult to implement for many reasons, primarily the lack of an economic profit, and unlikely will be conducted unless the initiative starts from governments.

Future research is awaited to address other not negligible issues. First, it is necessary to clarify definitively the CV interaction of metformin with SGLT-Is. Second, the metformin protection against HF is worthy of more extensive investigation even in people without concomitant diabetes, since its cardioprotective properties detached from antihyperglycemic effectiveness. In this matter, the ongoing DANHEART is the first study powered to address the effect of metformin (and of hydralazine-isosorbide dinitrate) in people with prediabetes or diabetes suffering from HFrEF [218]. Other data of interest will be provided by a large US trial evaluating the effects of extended-release metformin on clinical outcomes among nearly 8,000 patients with prediabetes and established atherosclerotic CVD, in which hospitalization for HF is a secondary outcome measure (VA-IMPACT; NCT02915198). This study 
was placed on temporary administrative hold since the COVID-19 pandemic (last update posted: 24 September 2021). Another placebo-controlled trial is evaluating the effects of prolonged-release metformin on the risk of $\mathrm{CV}$ events in patients with dysglycemia and high CV risk [219].

Finally, it can be appealing to explore if metformin may be an efficient therapeutic approach for the HFpEF phenotype, a condition notoriously linked to systemic metabolic or inflammatory diseases and for which no established therapies currently exist.

Author Contributions: Conceptualization, T.S. and F.C.S.; investigation, A.C., E.V., F.C., A.D.M. and G.A.; writing-original draft preparation, T.S., R.G. and F.C.S. writing-review and editing, T.S., R.G. and F.C.S.; supervision, T.S., L.R., R.M., C.S. and F.C.S. All authors have read and agreed to the published version of the manuscript.

Funding: This research received no external funding.

Institutional Review Board Statement: Not applicable.

Informed Consent Statement: Not applicable.

Data Availability Statement: Not available.

Acknowledgments: Raffaele Galiero was supported by the Programma VALERE, University of Campania "Luigi Vanvitelli".

Conflicts of Interest: The authors declare no conflict of interest.

\begin{abstract}
Abbreviations
ACE-I: angiotensin II inhibitor; AngII: angiotensin II; ADA: American Diabetes Association; AGE: advanced glycation endproducts; AMPK: AMP-dependent kinase; AT1R: AngII type 1 receptor; CAD: coronary artery disease; CV: cardiovascular; CVD: cardiovascular disease; CVOTs: cardiovascular outcome trials; eEF2: eukariotic elongation factor-2 kinase; eNOS: endothelial nitric oxide synthase; ER stress: endoplasmic reticulum stress; FA: fatty acid; GLP1-RAs: glucagon-like peptide-1 receptor agonists; GLUT4: glucose transporter protein type-4; HbA1c: hemoglobin A1c; HF: heart failure; HFpEF: HF with preserved ejection fraction; HFrEF: HF with reduced ejection fraction; iNOS: inducible nitric oxide synthase; JNK: c-Jun N-terminal kinase; LPS: lipopolysaccharide; mTOR: mechanistic target of rapamycin; $\mathrm{MI}$ : myocardial infarction; $\mathrm{MVO}_{2}$ : myocardial oxygen consumption; NF-kB: nuclear factor-kB; NO: nitric oxide; NOS: NO synthase; OCT: organic cation transporter; PFK1 phosphofructokinase 1; PGC1 $\alpha$ : peroxisome proliferator-activated receptor-g coactivator-1 $\alpha$; p70S6K: protein kinase 70S6; PKA protein kinase A; RCT: randomized controlled trial; SGLT2-Is: sodium glucose co-transporter-2 inhibitors; SIRT1-2-3: deacetylase Sirtuin 1-2-3; ROS: reactive oxygen species; T2DM: type 2 diabetes mellitus; TGF- $\beta 1$ : transforming growth factor $\beta 1$; TLR4: Toll-like receptor 4.
\end{abstract}

\title{
References
}

1. Salvatore, T.; Pafundi, P.C.; Marfella, R.; Sardu, C.; Rinaldi, L.; Monaco, L.; Ricozzi, C.; Imbriani, S.; Nevola, R.; Adinolfi, L.E.; et al. Metformin lactic acidosis: Should we still be afraid? Diabetes Res. Clin. Pract. 2019, 157, 107879. [CrossRef] [PubMed]

2. Witters, L.A. The blooming of the French lilac. J. Clin. Investig. 2001, 108, 1105-1107. [CrossRef]

3. Vaduganathan, M.; Fonarow, G.C.; Greene, S.J.; DeVore, A.D.; Kavati, A.; Sikirica, S.; Albert, N.M.; Duffy, C.I.; Hill, C.L.; Patterson, J.H.; et al. Contemporary treatment patterns and clinical outcomes of comorbid diabetes mellitus and HFrEF: The CHAMP-HF Registry. JACC Heart Fail. 2020, 8, 469-480. [CrossRef] [PubMed]

4. UK Prospective Diabetes Study (UKPDS) Group. Effect of intensive blood-glucose control with metformin on complications in overweight patients with type 2 diabetes (UKPDS 34). Lancet 1998, 352, 854-865, Erratum in 1998, 352, 1558. [CrossRef]

5. Holman, R.R.; Paul, S.K.; Bethel, M.A.; Matthews, D.R.; Neil, H.A. 10-year follow-up of intensive glucose control in type 2 diabetes. N. Engl. J. Med. 2008, 359, 1577-1589. [CrossRef]

6. Scheen, A.J.; Paquot, N. Metformin revisited: A critical review of the benefit-risk balance in at-risk patients with type 2 diabetes. Diabetes Metab. 2013, 39, 179-190. [CrossRef]

7. Salvatore, T.; Pafundi, P.C.; Galiero, R.; Rinaldi, L.; Caturano, A.; Vetrano, E.; Aprea, C.; Albanese, G.; Di Martino, A.; Ricozzi, C.; et al. Can metformin exert as an active drug on endothelial dysfunction in diabetic subjects? Biomedicines 2020, 9, 3. [CrossRef] 
8. Nathan, D.M.; Buse, J.B.; Davidson, M.B.; Heine, R.J.; Holman, R.R.; Sherwin, R.; Zinman, B.; Professional Practice Committee, American Diabetes Association; European Association for the Study of Diabetes. Management of hyperglycaemia in type 2 diabetes: A consensus algorithm for the initiation and adjustment of therapy. A consensus statement from the American Diabetes Asso-ciation and the European Association for the Study of Diabetes. Diabetologia 2006, 49, 1711-1721, Erratum in 2006, 49, 2816-2818. [CrossRef]

9. American Diabetes Association. 9. Pharmacologic approaches to glycemic treatment: Standards of medical care in diabetes-2021. Diabetes Care 2021, 44 (Suppl. 1), S111-S124. [CrossRef] [PubMed]

10. Misbin, R.I. The phantom of lactic acidosis due to metformin in patients with diabetes. Diabetes Care 2004, 27, 1791-1793. [CrossRef]

11. Holstein, A.; Nahrwold, D.; Hinze, S.; Egberts, E.H. Contra-indications to metformin therapy are largely disregarded. Diabet. Med. 1999, 16, 692-696. [CrossRef]

12. Salpeter, S.R.; Greyber, E.; Pasternak, G.A.; Salpeter, E.E. Risk of fatal and nonfatal lactic acidosis with metformin use in type 2 diabetes mellitus: Systematic review and meta-analysis. Arch. Intern. Med. 2003, 163, 2594-2602. [CrossRef]

13. Masoudi, F.A.; Inzucchi, S.E.; Wang, Y.; Havranek, E.P.; Foody, J.M.; Krumholz, H.M. Thiazolidinediones, metformin, and outcomes in older patients with diabetes and heart failure: An observational study. Circulation 2005, 111, 583-590. [CrossRef] [PubMed]

14. Eurich, D.T.; Majumdar, S.R.; McAlister, F.A.; Tsuyuki, R.T.; Johnson, J.A. Improved clinical outcomes associated with metformin in patients with diabetes and heart failure. Diabetes Care 2005, 28, 2345-2351. [CrossRef]

15. Kristensen, S.L.; Rø rth, R.; Jhund, P.S.; Docherty, K.F.; Sattar, N.; Preiss, D.; Kø ber, L.; Petrie, M.C.; McMurray, J.J.V. Cardiovascular, mortality, and kidney outcomes with GLP-1 receptor agonists in patients with type 2 diabetes: A systematic review and me-taanalysis of cardiovascular outcome trials. Lancet Diabetes Endocrinol. 2019, 7, 776-785. [CrossRef]

16. Kluger, A.Y.; Tecson, K.M.; Lee, A.Y.; Lerma, E.V.; Rangaswami, J.; Lepor, N.E.; Cobble, M.E.; McCullough, P.A. Class effects of SGLT2 inhibitors on cardiorenal outcomes. Cardiovasc. Diabetol. 2019, 18, 99. [CrossRef]

17. Cosentino, F.; Grant, P.J.; Aboyans, V.; Bailey, C.J.; Ceriello, A.; Delgado, V.; Federici, M.; Filippatos, G.; Grobbee, D.E.; ESC Scientific Document Group; et al. 2019 ESC Guidelines on diabetes, pre-diabetes, and cardiovascular diseases developed in collaboration with the EASD. Eur. Heart J. 2020, 41, 255-323. [CrossRef]

18. Neuen, B.L.; Arnott, C.; Perkovic, V.; Figtree, G.; de Zeeuw, D.; Fulcher, G.; Jun, M.; Jardine, M.J.; Zoungas, S.; Pollock, C.; et al. Sodium-glucose co-transporter-2 inhibitors with and without metformin: A meta-analysis of cardi-ovascular, kidney and mortality outcomes. Diabetes Obes. Metab. 2021, 23, 382-390. [CrossRef] [PubMed]

19. Tsapas, A.; Karagiannis, T.; Avgerinos, I.; Liakos, A.; Bekiari, E. GLP-1 receptor agonists for cardiovascular outcomes with and without metformin. A systematic review and meta-analysis of cardiovascular outcomes trials. Diabetes Res. Clin. Pract. 2021, 177, 108921. [CrossRef] [PubMed]

20. Inzucchi, S.E.; Fitchett, D.; Jurišić-Eržen, D.; Woo, V.; Hantel, S.; Janista, C.; Kaspers, S.; George, J.T.; Zinman, B. EMPA-REG OUTCOME $^{\circledR}$ Investigators: Are the cardiovascular and kidney benefits of empagliflozin influenced by baseline glucose-lowering therapy? Diabetes Obes. Metab. 2020, 22, 631-639. [CrossRef]

21. Neal, B.; Perkovic, V.; Mahaffey, K.W.; de Zeeuw, D.; Fulcher, G.; Erondu, N.; Shaw, W.; Law, G.; Desai, M.; Matthews, D.R. Canagliflozin and cardiovascular and renal events in type 2 diabetes. N. Engl. J. Med. 2017, 377, 644-657. [CrossRef]

22. Packer, M. Does Metformin Interfere With the Cardiovascular Benefits of SGLT2 Inhibitors? Questions about its role as the cornerstone of diabetes treatment. Am. J. Med. 2020, 133, 781-782. [CrossRef]

23. Sasso, F.C.; Pafundi, P.C.; Simeon, V.; De Nicola, L.; Chiodini, P.; Galiero, R.; Rinaldi, L.; Nevola, R.; Salvatore, T.; NID-2 Study Group Investigators; et al. Efficacy and durability of multifactorial intervention on mortality and MACEs: A randomized clinical trial in type-2 diabetic kidney disease. Cardiovasc. Diabetol. 2021, 20, 145. [CrossRef]

24. Sasso, F.C.; Salvatore, T.; Tranchino, G.; Cozzolino, D.; Caruso, A.A.; Persico, M.; Gentile, S.; Torella, D.; Torella, R. Cochlear dysfunction in type 2 diabetes: A complication independent of neuropathy and acute hyperglycemia. Metabolism 1999, 48, 1346-1350. [CrossRef]

25. Masarone, M.; Rosato, V.; Aglitti, A.; Bucci, T.; Caruso, R.; Salvatore, T.; Sasso, F.C.; Tripodi, M.F.; Persico, M. Liver biopsy in type 2 diabetes mellitus: Steatohepatitis represents the sole feature of liver damage. PLoS ONE 2017, 12, e0178473. [CrossRef] [PubMed]

26. Lombardi, R.; Airaghi, L.; Targher, G.; Serviddio, G.; Maffi, G.; Mantovani, A.; Maffeis, C.; Colecchia, A.; Villani, R.; Rinaldi, L.; et al. Liver fibrosis by FibroScan ${ }^{\circledR}$ independently of established cardiovascular risk pa-rameters associates with macrovascular and microvascular complications in patients with type 2 diabetes. Liver Int. 2020, 40, 347-354. [CrossRef] [PubMed]

27. Kannel, W.B.; McGee, D.L. Diabetes and cardiovascular disease. The Framingham study. JAMA 1979, 241, 2035-2038. [CrossRef]

28. Nichols, G.A.; Hillier, T.A.; Erbey, J.R.; Brown, J.B. Congestive heart failure in type 2 diabetes: Prevalence, incidence, and risk factors. Diabetes Care 2001, 24, 1614-1619. [CrossRef] [PubMed]

29. Parving, H.H.; Brenner, B.M.; McMurray, J.J.; de Zeeuw, D.; Haffner, S.M.; Solomon, S.D.; Chaturvedi, N.; Persson, F.; Desai, A.S.; ALTITUDE Investigators; et al. Cardiorenal end points in a trial of aliskiren for type 2 diabetes. N. Engl. J. Med. 2012, 367, 2204-2213. [CrossRef]

30. Bertoni, A.G.; Hundley, W.G.; Massing, M.W.; Bonds, D.E.; Burke, G.L.; Goff, D.C., Jr. Heart failure prevalence, incidence, and mortality in the elderly with diabetes. Diabetes Care 2004, 27, 699-703. [CrossRef]

31. Salvatore, T.; Pafundi, P.C.; Galiero, R.; Albanese, G.; Di Martino, A.; Caturano, A.; Vetrano, E.; Rinaldi, L.; Sasso, F.C. The Diabetic Cardiomyopathy: The Contributing Pathophysiological Mechanisms. Front. Med. 2021, 8, 695792. [CrossRef] [PubMed] 
32. Greenberg, B.H.; Abraham, W.T.; Albert, N.M.; Chiswell, K.; Clare, R.; Stough, W.G.; Gheorghiade, M.; O'Connor, C.M.; Sun, J.L.; Yancy, C.W.; et al. Influence of diabetes on characteristics and outcomes in patients hospitalized with heart failure: A report from the organized program to initiate lifesaving treatment in hospitalized patients with heart failure (OPTIMIZEHF). Am. Heart J. 2007, 154, 277.e1-277.e8. [CrossRef] [PubMed]

33. Sarma, S.; Mentz, R.J.; Kwasny, M.J.; Fought, A.J.; Huffman, M.; Subacius, H.; Nodari, S.; Konstam, M.; Swedberg, K.; EVEREST Investigators; et al. Association between diabetes mellitus and post-discharge outcomes in patients hospitalized with heart failure: Findings from the EVEREST trial. Eur. J. Heart Fail. 2013, 15, 194-202. [CrossRef] [PubMed]

34. Kristensen, S.L.; Preiss, D.; Jhund, P.S.; Squire, I.; Cardoso, J.S.; Merkely, B.; Martinez, F.; Starling, R.C.; Desai, A.S.; PARADIGMHF Investigators and committees; et al. Risk related to pre-diabetes mellitus and diabetes mellitus in heart failure with reduced ejection fraction: Insights from prospective comparison of ARNI with ACEI to determine impact on global mortality and morbidity in heart failure trial. Circ. Heart Fail. 2016, 9, e002560. [CrossRef]

35. Zareini, B.; Rørth, R.; Holt, A.; Mogensen, U.M.; Selmer, C.; Gislason, G.; Schou, M.; Køber, L.; Torp-Pedersen, C.; Lamberts, M.; et al. Heart failure and the prognostic impact and incidence of new-onset of diabetes mellitus: A nationwide cohort study. Cardiovasc. Diabetol. 2019, 18, 79. [CrossRef] [PubMed]

36. Solomon, S.D.; Rizkala, A.R.; Lefkowitz, M.P.; Shi, V.C.; Gong, J.; Anavekar, N.; Anker, S.D.; Arango, J.L.; Arenas, J.L.; Atar, D.; et al. Baseline characteristics of patients with heart failure and preserved ejection fraction in the PARAGON-HF trial. Circ. Heart Fail. 2018, 11, e004962. [CrossRef]

37. Kristensen, S.L.; Mogensen, U.M.; Jhund, P.S.; Petrie, M.C.; Preiss, D.; Win, S.; Køber, L.; McKelvie, R.S.; Zile, M.R.; Anand, I.S.; et al. Clinical and echocardiographic characteristics and cardiovascular outcomes according to diabetes status in patients with heart failure and preserved ejection fraction: A report from the I-Preserve trial (irbesartan in heart failure with preserved ejection fraction). Circulation 2017, 135, 724-735. [CrossRef]

38. MacDonald, M.R.; Petrie, M.C.; Varyani, F.; Ostergren, J.; Michelson, E.L.; Young, J.B.; Solomon, S.D.; Granger, C.B.; Swedberg, K.; Yusuf, S.; et al. Impact of diabetes on outcomes in patients with low and preserved ejection fraction heart failure: An analysis of the Candesartan in Heart failure: Assessment of Reduction in Mortality and morbidity (CHARM) programme. Eur. Heart J. 2008, 29, 1377-1385. [CrossRef] [PubMed]

39. Swan, J.W.; Anker, S.D.; Walton, C.; Godsland, I.F.; Clark, A.L.; Leyva, F.; Stevenson, J.C.; Coats, A.J. Insulin resistance in chronic heart failure: Relation to severity and etiology of heart failure. J. Am. Coll. Cardiol. 1997, 30, 527-532. [CrossRef]

40. Gustafsson, I.; Brendorp, B.; Seibaek, M.; Burchardt, H.; Hildebrandt, P.; Køber, L.; Torp-Pedersen, C.; Danish Investigatord of Arrhythmia and Mortality on Dofetilde Study Group. Influence of diabetes and diabetes-gender interaction on the risk of death in patients hospitalized with congestive heart failure. J. Am. Coll. Cardiol. 2004, 43, 771-777. [CrossRef]

41. Doehner, W.; Rauchhaus, M.; Ponikowski, P.; Godsland, I.F.; von Haehling, S.; Okonko, D.O.; Leyva, F.; Proudler, A.J.; Coats, A.J.; Anker, S.D. Impaired insulin sensitivity as an independent risk factor for mortality in patients with stable chronic heart failure. J. Am. Coll. Cardiol. 2005, 46, 1019-1026. [CrossRef] [PubMed]

42. Targher, G.; Dauriz, M.; Laroche, C.; Temporelli, P.L.; Hassanein, M.; Seferovic, P.M.; Drozdz, J.; Ferrari, R.; Anker, S.; Coats, A.; et al. In-hospital and 1-year mortality associated with diabetes in patients with acute heart failure: Results from the ESC-HFA Heart Failure Long-Term Registry. Eur. J. Heart Fail. 2017, 19, 54-65. [CrossRef]

43. Cavender, M.A.; Steg, P.G.; Smith, S.C., Jr.; Eagle, K.; Ohman, E.M.; Goto, S.; Kuder, J.; Im, K.; Wilson, P.W.; Bhatt, D.L.; et al. Impact of diabetes mellitus on hospitalization for heart failure, cardiovascular events, and death: Outcomes at 4 years from the reduction of atherothrombosis for continued health (REACH) registry. Circulation 2015, 132, 923-931. [CrossRef] [PubMed]

44. Bertoni, A.G.; Kirk, J.K.; Goff, D.C., Jr.; Wagenknecht, L.E. Excess mortality related to diabetes mellitus in elderly Medicare benefi-ciaries. Ann. Epidemiol. 2004, 14, 362-367. [CrossRef] [PubMed]

45. Hardie, D.G. The AMP-activated protein kinase pathway-New players upstream and downstream. J. Cell Sci. 2004, 117, 5479-5487. [CrossRef]

46. Hardie, D.G.; Carling, D. The AMP-activated protein kinase-Fuel gauge of the mammalian cell? Eur. J. Biochem. 1997, 246, 259-273. [CrossRef]

47. Woods, A.; Vertommen, D.; Neumann, D.; Turk, R.; Bayliss, J.; Schlattner, U.; Wallimann, T.; Carling, D.; Rider, M.H. Identification of phosphorylation sites in AMP-activated protein kinase (AMPK) for upstream AMPK kinases and study of their roles by site-directed mutagenesis. J. Biol. Chem. 2003, 278, 28434-28442. [CrossRef]

48. Timm, K.N.; Tyler, D.J. The role of AMPK activation for cardioprotection in doxorubicin-induced cardiotoxicity. Cardiovasc. Drugs Ther. 2020, 34, 255-269. [CrossRef]

49. Cantó, C.; Auwerx, J. AMP-activated protein kinase and its downstream transcriptional pathways. Cell Mol. Life Sci. 2010, 67, 3407-3423. [CrossRef]

50. Li, Y.; Xu, S.; Mihaylova, M.M.; Zheng, B.; Hou, X.; Jiang, B.; Park, O.; Luo, Z.; Lefai, E.; Shyy, J.Y.; et al. AMPK phosphorylates and inhibits SREBP activity to attenuate hepatic steatosis and atherosclerosis in diet-induced insulin-resistant mice. Cell Metab. 2011, 13, 376-388. [CrossRef]

51. Owen, M.R.; Doran, E.; Halestrap, A.P. Evidence that metformin exerts its anti-diabetic effects through inhibition of complex 1 of the mitochondrial respiratory chain. Biochem. J. 2000, 348, 607-614. [CrossRef] 
52. Hunter, R.W.; Hughey, C.C.; Lantier, L.; Sundelin, E.I.; Peggie, M.; Zeqiraj, E.; Sicheri, F.; Jessen, N.; Wasserman, D.H.; Sakamoto, K. Metformin reduces liver glucose production by inhibition of fructose-1-6-bisphosphatase. Nat. Med. 2018, 24, $1395-1406$. [CrossRef] [PubMed]

53. Kim, J.; Yang, G.; Kim, Y.; Kim, J.; Ha, J. AMPK activators: Mechanisms of action and physiological activities. Exp. Mol. Med. 2016, 48, e224. [CrossRef] [PubMed]

54. Ouyang, J.; Parakhia, R.A.; Ochs, R.S. Metformin activates AMP kinase through inhibition of AMP deaminase. J. Biol Chem. 2011, 286, 1-11. [CrossRef] [PubMed]

55. Coughlan, K.A.; Valentine, R.J.; Ruderman, N.B.; Saha, A.K. AMPK activation: A therapeutic target for type 2 diabetes? Diabetes Metab. Syndr. Obes. 2014, 7, 241-253. [CrossRef]

56. Shaw, R.J.; Lamia, K.A.; Vasquez, D.; Koo, S.H.; Bardeesy, N.; Depinho, R.A.; Montminy, M.; Cantley, L.C. The kinase LKB1 mediates glucose homeostasis in liver and therapeutic effects of metformin. Science 2005, 310, 1642-1646. [CrossRef]

57. Yang, X.; Xu, Z.; Zhang, C.; Cai, Z.; Zhang, J. Metformin, beyond an insulin sensitizer, targeting heart and pancreatic $\beta$ cells. Biochim. Biophys. Acta Mol. Basis Dis. 2017, 1863, 1984-1990. [CrossRef]

58. Petrie, J.R.; Chaturvedi, N.; Ford, I.; Brouwers, M.C.G.J.; Greenlaw, N.; Tillin, T.; Hramiak, I.; Hughes, A.D.; Jenkins, A.J.; Klein, B.E.K.; et al. Cardiovascular and metabolic effects of metformin in patients with type 1 diabetes (REMOVAL): A double-blind, randomised, placebo-controlled trial. Lancet Diabetes Endocrinol. 2017, 5, 597-609. [CrossRef]

59. Petersen, J.S.; Andersen, D.; Muntzel, M.S.; Diemer, N.H.; Holstein-Rathlou, N.H. Intracerebroventricular metformin attenuates salt-induced hypertension in spontaneously hypertensive rats. Am. J. Hypertens. 2001, 14, 1116-1122. [CrossRef]

60. Zhou, L.; Liu, H.; Wen, X.; Peng, Y.; Tian, Y.; Zhao, L. Effects of metformin on blood pressure in nondiabetic patients: A meta-analysis of randomized controlled trials. J. Hypertens. 2017, 35, 18-26. [CrossRef]

61. Mäkimattila, S.; Nikkilä, K.; Yki-Järvinen, H. Causes of weight gain during insulin therapy with and without metformin in patients with Type II diabetes mellitus. Diabetologia 1999, 42, 406-412. [CrossRef]

62. Anabtawi, A.; Miles, J.M. Metformin: Nonglycemic effects and potential novel indications. Endocr Pract. 2016, $22,999-1007$. [CrossRef] [PubMed]

63. Wulffelé, M.G.; Kooy, A.; de Zeeuw, D.; Stehouwer, C.D.; Gansevoort, R.T. The effect of metformin on blood pressure, plasma cholesterol and triglycerides in type 2 diabetes mellitus: A systematic review. J. Intern. Med. 2004, 256, 1-14. [CrossRef] [PubMed]

64. Marfella, R.; Sasso, F.C.; Cacciapuoti, F.; Portoghese, M.; Rizzo, M.R.; Siniscalchi, M.; Carbonara, O.; Ferraraccio, F.; Torella, M.; Petrella, A.; et al. Tight glycemic control may increase regenerative potential of myocardium during acute infarction. J. Clin. Endocrinol. Metab. 2012, 97, 933-942. [CrossRef]

65. Sasso, F.C.; Rinaldi, L.; Lascar, N.; Marrone, A.; Pafundi, P.C.; Adinolfi, L.E.; Marfella, R. Role of tight glycemic control during acute coronary syndrome on cv outcome in type 2 diabetes. J. Diabetes Res. 2018, 2018, 3106056. [CrossRef] [PubMed]

66. Caturano, A.; Galiero, R.; Pafundi, P.C.; Cesaro, A.; Vetrano, E.; Palmiero, G.; Rinaldi, L.; Salvatore, T.; Marfella, R.; Sardu, C.; et al. Does a strict glycemic control during acute coronary syndrome play a cardioprotective effect? Pathophysiology and clinical evidence. Diabetes Res. Clin. Pract. 2021, 178, 108959. [CrossRef]

67. UK Prospective Diabetes Study (UKPDS) Group. Intensive blood-glucose control with sulphonylureas or insulin compared with conventional treatment and risk of compli-cations in patients with type 2 diabetes (UKPDS 33). Lancet 1998, 352, 837-853, Erratum in 1999, 354, 602. [CrossRef]

68. Action to Control Cardiovascular Risk in Diabetes Study Group. Effects of intensive glucose lowering in type 2 diabetes. N. Engl. J. Med. 2008, 358, 2545-2559. [CrossRef] [PubMed]

69. ADVANCE Collaborative Group. Intensive blood glucose control and vascular outcomes in patients with type 2 diabetes. $N$. Engl. J. Med. 2008, 358, 2560-2572. [CrossRef]

70. Anderson, R.J.; Bahn, G.D.; Moritz, T.E.; Kaufman, D.; Abraira, C.; Duckworth, W.; VADT Study Group. Blood pressure and cardiovascular disease risk in the Veterans Affairs Diabetes Trial. Diabetes Care 2011, 34, 34-38. [CrossRef]

71. Zilov, A.V.; Abdelaziz, S.I.; AlShammary, A.; Al Zahrani, A.; Amir, A.; Assaad Khalil, S.H.; Brand, K.; Elkafrawy, N.; Hassoun, A.A.K.; Jahed, A.; et al. Mechanisms of action of metformin with special reference to cardiovascular protection. Diabetes Metab. Res. Rev. 2019, 35, e3173. [CrossRef]

72. Luo, F.; Das, A.; Chen, J.; Wu, P.; Li, X.; Fang, Z. Metformin in patients with and without diabetes: A paradigm shift in cardiovascular disease management. Cardiovasc. Diabetol. 2019, 18, 54. [CrossRef] [PubMed]

73. Shang, F.; Zhang, J.; Li, Z.; Zhang, J.; Yin, Y.; Wang, Y.; Marin, T.L.; Gongol, B.; Xiao, H.; Zhang, Y.Y.; et al. Cardiovascular protective effect of metformin and telmisartan: Reduction of parp1 activity via the ampk-parp1 cascade. PLOS ONE 2016, 11, e0151845. [CrossRef]

74. Torella, D.; Iaconetti, C.; Tarallo, R.; Marino, F.; Giurato, G.; Veneziano, C.; Aquila, I.; Scalise, M.; Mancuso, T.; Cianflone, E.; et al. Mirna regulation of the hyperproliferative phenotype of vascular smooth muscle cells in diabetes. Diabetes 2018, 67, 2554-2568. [CrossRef]

75. Lozano, E.; Briz, O.; Macias, R.I.R.; Serrano, M.A.; Marin, J.J.G.; Herraez, E. Genetic heterogeneity of slc22 family of transporters in drug disposition. J. Pers. Med. 2018, 8, 14. [CrossRef] [PubMed]

76. Kim, T.T.; Dyck, J.R. Is AMPK the savior of the failing heart? Trends Endocrinol. Metab. 2015, 26, 40-48. [CrossRef] [PubMed]

77. Li, X.; Liu, J.; Lu, Q.; Ren, D.; Sun, X.; Rousselle, T.; Tan, Y.; Li, J. AMPK: A therapeutic target of heart failure-not only metabolism regulation. Biosci. Rep. 2019, 39, BSR20181767. [CrossRef] 
78. Varjabedian, L.; Bourji, M.; Pourafkari, L.; Nader, N.D. Cardioprotection by metformin: Beneficial effects beyond glucose reduction. Am. J. Cardiovasc. Drugs 2018, 18, 181-193. [CrossRef]

79. Gundewar, S.; Calvert, J.W.; Jha, S.; Toedt-Pingel, I.; Ji, S.Y.; Nunez, D.; Ramachandran, A.; Anaya-Cisneros, M.; Tian, R.; Lefer, D.J. Acti-vation of AMP-activated protein kinase by metformin improves left ventricular function and survival in heart failure. Circ. Res. 2009, 104, 403-411. [CrossRef]

80. Pascual, F.; Coleman, R.A. Fuel availability and fate in cardiac metabolism: A tale of two substrates. Biochim. Biophys. Acta 2016, 1861, 1425-1433. [CrossRef]

81. Taegtmeyer, H.; Young, M.E.; Lopaschuk, G.D.; Abel, E.D.; Brunengraber, H.; Darley-Usmar, V.; Des Rosiers, C.; Gerszten, R.; Glatz, J.F.; Griffin, J.L.; et al. American heart association council on basic cardiovascular sciences. assessing cardiac metabolism: A scientific statement from the american heart association. Circ. Res. 2016, 118, 1659-1701. [CrossRef]

82. Neubauer, S. The failing heart-An engine out of fuel. N. Engl. J. Med. 2007, 356, 1140-1151. [CrossRef] [PubMed]

83. Doenst, T.; Nguyen, T.D.; Abel, E.D. Cardiac metabolism in heart failure: Implications beyond ATP production. Circ. Res. 2013, 113, 709-724. [CrossRef]

84. Sun, D.; Yang, F. Metformin improves cardiac function in mice with heart failure after myocardial infarction by regulating mitochondrial energy metabolism. Biochem. Biophys. Res. Commun. 2017, 486, 329-335. [CrossRef] [PubMed]

85. Dziubak, A.; Wójcicka, G.; Wojtak, A.; Bełtowski, J. Metabolic effects of metformin in the failing heart. Int. J. Mol. Sci. 2018, 19, 2869. [CrossRef]

86. Bertrand, L.; Ginion, A.; Beauloye, C.; Hebert, A.D.; Guigas, B.; Hue, L.; Vanoverschelde, J.L. AMPK activation restores the stimulation of glucose uptake in an in vitro model of insulin-resistant cardiomyocytes via the activation of protein kinase B. Am. J. Physiol. Heart Circ. Physiol. 2006, 291, H239-H250. [CrossRef] [PubMed]

87. Jiao, Z.; Chen, Y.; Xie, Y.; Li, Y.; Li, Z. Metformin protects against insulin resistance induced by high uric acid in cardiomyocytes via AMPK signalling pathways in vitro and in vivo. J. Cell Mol. Med. 2021, 25, 6733-6745. [CrossRef]

88. Nascimben, L.; Ingwall, J.S.; Lorell, B.H.; Pinz, I.; Schultz, V.; Tornheim, K.; Tian, R. Mechanisms for increased glycolysis in the hypertrophied rat heart. Hypertension 2004, 44, 662-667. [CrossRef] [PubMed]

89. Sen, S.; Kundu, B.K.; Wu, H.C.; Hashmi, S.S.; Guthrie, P.; Locke, L.W.; Roy, R.J.; Matherne, G.P.; Berr, S.S.; Terwelp, M.; et al. Glucose regulation of load-induced mTOR signaling and ER stress in mammalian heart. J. Am. Heart Assoc. 2013, 2, e004796. [CrossRef]

90. Goldberg, I.J.; Trent, C.M.; Schulze, P.C. Lipid metabolism and toxicity in the heart. Cell Metab. 2012, 15, 805-812. [CrossRef]

91. Miklankova, D.; Markova, I.; Hüttl, M.; Zapletalova, I.; Poruba, M.; Malinska, H. Metformin affects cardiac arachidonic acid metabolism and cardiac lipid metabolite storage in a prediabetic rat model. Int. J. Mol. Sci. 2021, 22, 7680. [CrossRef]

92. Marfella, R.; Amarelli, C.; Cacciatore, F.; Balestrieri, M.L.; Mansueto, G.; D’Onofrio, N.; Esposito, S.; Mattucci, I.; Salerno, G.; De Feo, M.; et al. Lipid accumulation in hearts transplanted from nondiabetic donors to diabetic recipients. J. Am. Coll. Cardiol. 2020, 75, 1249-1262. [CrossRef] [PubMed]

93. Bertero, E.; Maack, C. Metabolic remodelling in heart failure. Nat. Rev. Cardiol. 2018, 15, 457-470. [CrossRef] [PubMed]

94. Schaper, J.; Froede, R.; Hein, S.; Buck, A.; Hashizume, H.; Speiser, B.; Friedl, A.; Bleese, N. Impairment of the myocardial ultrastructure and changes of the cytoskeleton in dilated cardiomyopathy. Circulation 1991, 83, 504-514. [CrossRef]

95. Sabbah, H.N.; Sharov, V.; Riddle, J.M.; Kono, T.; Lesch, M.; Goldstein, S. Mitochondrial abnormalities in myocardium of dogs with chronic heart failure. J. Mol. Cell Cardiol. 1992, 24, 1333-1347. [CrossRef]

96. Psotka, M.A.; Gottlieb, S.S.; Francis, G.S.; Allen, L.A.; Teerlink, J.R.; Adams, K.F., Jr.; Rosano, G.M.C.; Lancellotti, P. Cardiac calcitropes, myotropes, and mitotropes: JACC review topic of the week. J. Am. Coll. Cardiol. 2019, 73, 2345-2353. [CrossRef]

97. Larsen, A.H.; Jessen, N.; Nørrelund, H.; Tolbod, L.P.; Harms, H.J.; Feddersen, S.; Nielsen, F.; Brøsen, K.; Hansson, N.H.; Frøkiaer, J.; et al. A randomised, double-blind, placebo-controlled trial of metformin on myocardial efficiency in insulin-resistant chronic heart failure patients without diabetes. Eur. J. Heart Fail. 2020, 22, 1628-1637. [CrossRef]

98. Pillai, V.B.; Bindu, S.; Sharp, W.; Fang, Y.H.; Kim, G.; Gupta, M.; Samant, S.; Gupta, M.P. Sirt3 protects mitochondrial DNA damage and blocks the development of doxorubicin-induced cardiomyopathy in mice. Am. J. Physiol. Heart Circ. Physiol. 2016, 310, H962-H972. [CrossRef] [PubMed]

99. Cho, Y.; Hazen, B.C.; Russell, A.P.; Kralli, A. Peroxisome proliferator-activated receptor $\gamma$ coactivator 1 (PGC-1)- and estro-genrelated receptor (ERR)-induced regulator in muscle 1 (Perm1) is a tissue-specific regulator of oxidative capacity in skeletal muscle cells. J. Biol. Chem. 2013, 288, 25207-25218. [CrossRef]

100. Beanlands, R.S.; Nahmias, C.; Gordon, E.; Coates, G.; deKemp, R.; Firnau, G.; Fallen, E. The effects of beta(1)-blockade on oxidative metabolism and the metabolic cost of ventricular work in patients with left ventricular dysfunction: A double-blind, pla-cebo-controlled, positron-emission tomography study. Circulation 2000, 102, 2070-2075. [CrossRef] [PubMed]

101. Tsutsui, H.; Kinugawa, S.; Matsushima, S. Oxidative stress and heart failure. Am. J. Physiol. Heart Circ. Physiol. 2011, 301, H2181-H2190. [CrossRef]

102. Förstermann, U.; Kleinert, H. Nitric oxide synthase: Expression and expressional control of the three isoforms. Naunyn Schmiedebergs Arch. Pharmacol. 1995, 352, 351-364. [CrossRef]

103. Yang, B.; Larson, D.F.; Watson, R.R. Modulation of iNOS activity in age-related cardiac dysfunction. Life Sci. 2004, 75, 655-667. [CrossRef] 
104. Davis, B.J.; Xie, Z.; Viollet, B.; Zou, M.-H. Activation of the AMP-activated kinase by antidiabetes drug metformin stimulates nitric oxide synthesis in vivo by promoting the association of heat shock protein 90 and endothelial nitric oxide synthase. Diabetes 2006, 55, 496-505. [CrossRef]

105. Lefer, A.M. Attenuation of myocardial ischemia-reperfusion injury with nitric oxide replacement therapy. Ann. Thorac. Surg. 1995, 60, 847-851. [CrossRef]

106. Cittadini, A.; Napoli, R.; Monti, M.G.; Rea, D.; Longobardi, S.; Netti, P.A.; Walser, M.; Samà, M.; Aimaretti, G.; Isgaard, J.; et al. Metformin prevents the development of chronic heart failure in the SHHF rat model. Diabetes 2012, 61, 944-953. [CrossRef]

107. Lin, X.; Wang, Q.; Sun, S.; Xu, G.; Wu, Q.; Qi, M.; Bai, F.; Yu, J. Astragaloside IV promotes the eNOS/NO/cGMP pathway and improves left ventricular diastolic function in rats with metabolic syndrome. J. Int. Med. Res. 2020, 48, 300060519826848. [CrossRef]

108. Tsujino, M.; Hirata, Y.; Imai, T.; Kanno, K.; Eguchi, S.; Ito, H.; Marumo, F. Induction of nitric oxide synthase gene by interleukin-1 beta in cultured rat cardiocytes. Circulation 1994, 90, 375-383. [CrossRef] [PubMed]

109. Wang, H.W.; Lai, E.H.; Yang, C.N.; Lin, S.K.; Hong, C.Y.; Yang, H.; Chang, J.Z.; Kok, S.H. Intracanal metformin promotes healing of apical periodontitis via suppressing inducible nitric oxide synthase expression and monocyte recruitment. J. Endod. 2020, 46, 65-73. [CrossRef] [PubMed]

110. Vakifahmetoglu-Norberg, H.; Ouchida, A.T.; Norberg, E. The role of mitochondria in metabolism and cell death. Biochem. Biophys. Res. Commun. 2017, 482, 426-431. [CrossRef]

111. Liu, X.D.; Li, Y.G.; Wang, G.Y.; Bi, Y.G.; Zhao, Y.; Yan, M.L.; Liu, X.; Wei, M.; Wan, L.L.; Zhang, Q.Y. Metformin protects high glucose cultured cardiomyocytes from oxidative stress by promoting NDUFA13 expression and mitochondrial biogenesis via the AMPK signaling pathway. Mol. Med. Rep. 2020, 22, 5262-5270. [CrossRef] [PubMed]

112. Aggeli, I.K.; Beis, I.; Gaitanaki, C. ERKs and JNKs mediate hydrogen peroxide-induced Egr-1 expression and nuclear accumulation in H9c2 cells. Physiol. Res. 2010, 59, 443-454. [CrossRef] [PubMed]

113. Hu, M.; Ye, P.; Liao, H.; Chen, M.; Yang, F. Metformin protects H9C2 cardiomyocytes from high-glucose and hypoxia/reoxygenation injury via inhibition of reactive oxygen species generation and inflammatory responses: Role of AMPK and JNK. J. Diabetes Res. 2016, 2016, 2961954. [CrossRef] [PubMed]

114. Yang, L.; Zhao, D.; Ren, J.; Yang, J. Endoplasmic reticulum stress and protein quality control in diabetic cardiomyopathy. Biochim. Biophys. Acta 2015, 1852, 209-218. [CrossRef]

115. Chen, Q.; Thompson, J.; Hu, Y.; Das, A.; Lesnefsky, E.J. Metformin attenuates ER stress-induced mitochondrial dysfunction. Transl. Res. 2017, 190, 40-50. [CrossRef]

116. Li, H.; Chen, C.; Wang, D.W. Inflammatory cytokines, immune cells, and organ interactions in heart failure. Front. Physiol. 2021, 12, 695047. [CrossRef]

117. Bai, B.; Chen, H. Metformin: A novel weapon against inflammation. Front. Pharmacol. 2021, 12, 622262. [CrossRef]

118. Cameron, A.R.; Morrison, V.L.; Levin, D.; Mohan, M.; Forteath, C.; Beall, C.; McNeilly, A.D.; Balfour, D.J.; Savinko, T.; Wong, A.K.; et al. Anti-inflammatory effects of metformin irrespective of diabetes status. Circ. Res. 2016, 119, 652-665. [CrossRef]

119. Salvatore, T.; Pafundi, P.C.; Galiero, R.; Gjeloshi, K.; Masini, F.; Acierno, C.; Di Martino, A.; Albanese, G.; Alfano, M.; Rinaldi, L.; et al. Metformin: A potential therapeutic tool for rheumatologists. Pharmaceuticals 2020, 13, 234. [CrossRef]

120. Cheng, X.; Liu, Y.M.; Li, H.; Zhang, X.; Lei, F.; Qin, J.J.; Chen, Z.; Deng, K.Q.; Lin, L.; Chen, M.M.; et al. Metformin is associated with higher incidence of acidosis, but not mortality, in individuals with COVID-19 and pre-existing type 2 diabetes. Cell Metab. 2020, 32, 537-547.e3. [CrossRef]

121. Isoda, K.; Young, J.L.; Zirlik, A.; MacFarlane, L.A.; Tsuboi, N.; Gerdes, N.; Schönbeck, U.; Libby, P. Metformin inhibits proinflammatory responses and nuclear factor-kappaB in human vascular wall cells. Arter. Thromb. Vasc. Biol. 2006, 26, 611-617. [CrossRef] [PubMed]

122. Saisho, Y. Metformin and inflammation: Its potential beyond glucose-lowering effect. Endocr. Metab. Immune Disord. Drug Targets 2015, 15, 196-205. [CrossRef]

123. Soraya, H.; Farajnia, S.; Khani, S.; Rameshrad, M.; Khorrami, A.; Banani, A.; Maleki-Dizaji, N.; Garjani, A. Short-term treatment with metformin suppresses toll like receptors (TLRs) activity in isoproterenol-induced myocardial infarction in rat: Are AMPK and TLRs connected? Int. Immunopharmacol. 2012, 14, 785-791. [CrossRef]

124. Soraya, H.; Clanachan, A.S.; Rameshrad, M.; Maleki-Dizaji, N.; Ghazi-Khansari, M.; Garjani, A. Chronic treatment with metformin suppresses toll-like receptor 4 signaling and attenuates left ventricular dysfunction following myocardial infarction. Eur. J. Pharmacol. 2014, 737, 77-84. [CrossRef]

125. Yang, Y.; Lv, J.; Jiang, S.; Ma, Z.; Wang, D.; Hu, W.; Deng, C.; Fan, C.; Di, S.; Sun, Y.; et al. The emerging role of Toll-like receptor 4 in myocardial inflammation. Cell Death Dis. 2016, 7, e2234. [CrossRef] [PubMed]

126. Fei, Q.; Ma, H.; Zou, J.; Wang, W.; Zhu, L.; Deng, H.; Meng, M.; Tan, S.; Zhang, H.; Xiao, X.; et al. Metformin protects against ischaemic myocardial injury by alleviating autophagy-ROS-NLRP3-mediated inflammatory response in macrophages. J. Mol. Cell Cardiol. 2020, 145, 1-13. [CrossRef] [PubMed]

127. Yang, F.; Qin, Y.; Wang, Y.; Meng, S.; Xian, H.; Che, H.; Lv, J.; Li, Y.; Yu, Y.; Bai, Y.; et al. Metformin inhibits the NLRP3 inflammasome via AMPK/mTOR-dependent effects in diabetic cardiomyopathy. Int. J. Biol. Sci. 2019, 15, 1010-1019. [CrossRef] [PubMed]

128. Xie, Z.; Lau, K.; Eby, B.; Lozano, P.; He, C.; Pennington, B.; Li, H.; Rathi, S.; Dong, Y.; Tian, R.; et al. Improvement of cardiac functions by chronic metformin treatment is associated with enhanced cardiac autophagy in diabetic OVE26 mice. Diabetes 2011, 60, 1770-1778. [CrossRef] [PubMed] 
129. Simons, K.H.; de Jong, A.; Jukema, J.W.; de Vries, M.R.; Arens, R.; Quax, P.H.A. T cell co-stimulation and co-inhibition in cardiovascular disease: A double-edged sword. Nat. Rev. Cardiol. 2019, 16, 325-343. [CrossRef]

130. Nyambuya, T.M.; Dludla, P.V.; Mxinwa, V.; Mokgalaboni, K.; Ngcobo, S.R.; Tiano, L.; Nkambule, B.B. The impact of metformin and aspirin on T-cell mediated inflammation: A systematic review of in vitro and in vivo findings. Life Sci. 2020 255, 117854. [CrossRef]

131. Li, B.; Po, S.S.; Zhang, B.; Bai, F.; Li, J.; Qin, F.; Liu, N.; Sun, C.; Xiao, Y.; Tu, T.; et al. Metformin regulates adiponectin signalling in epicardial adipose tissue and reduces atrial fibrillation vulnerability. J. Cell Mol. Med. 2020, 24, 7751-7766. [CrossRef] [PubMed]

132. Ziyrek, M.; Kahraman, S.; Ozdemir, E.; Dogan, A. Metformin monotherapy significantly decreases epicardial adipose tissue thickness in newly diagnosed type 2 diabetes patients. Rev. Port. Cardiol. 2019, 38, 419-423. [CrossRef]

133. Packer, M. Drugs that ameliorate epicardial adipose tissue inflammation may have discordant effects in heart failure with a preserved ejection fraction as compared with a reduced ejection fraction. J. Card. Fail. 2019, 25, 986-1003. [CrossRef]

134. Sasaki, H.; Asanuma, H.; Fujita, M.; Takahama, H.; Wakeno, M.; Ito, S.; Ogai, A.; Asakura, M.; Kim, J.; Minamino, T.; et al. Metformin prevents progression of heart failure in dogs: Role of AMP-activated protein kinase. Circulation 2009, 119, 2568-2577. [CrossRef] [PubMed]

135. Pasumarthi, K.B.; Field, L.J. Cardiomyocyte cell cycle regulation. Circ. Res. 2002, 90, 1044-1054. [CrossRef] [PubMed]

136. Nakamura, M.; Sadoshima, J. Mechanisms of physiological and pathological cardiac hypertrophy. Nat. Rev. Cardiol. 2018, 15, 387-407. [CrossRef]

137. Ren, Z.; Yu, P.; Li, D.; Li, Z.; Liao, Y.; Wang, Y.; Zhou, B.; Wang, L. Single-cell reconstruction of progression trajectory reveals inter-vention principles in pathological cardiac hypertrophy. Circulation 2020, 141, 1704-1719. [CrossRef]

138. Ritterhoff, J.; Young, S.; Villet, O.; Shao, D.; Neto, F.C.; Bettcher, L.F.; Hsu, Y.A.; Kolwicz, S.C., Jr.; Raftery, D.; Tian, R. Metabolic remodeling promotes cardiac hypertrophy by directing glucose to aspartate biosynthesis. Circ. Res. 2020, 126, 182-196. [CrossRef]

139. Zarrinpashneh, E.; Beauloye, C.; Ginion, A.; Pouleur, A.C.; Havaux, X.; Hue, L.; Viollet, B.; Vanoverschelde, J.L.; Bertrand, L. AMPKalpha2 counteracts the development of cardiac hypertrophy induced by isoproterenol. Biochem. Biophys. Res. Commun. 2008, 376, 677-681. [CrossRef]

140. Blair, E.; Redwood, C.; Ashrafian, H.; Oliveira, M.; Broxholme, J.; Kerr, B.; Salmon, A.; Ostman-Smith, I.; Watkins, H. Mutations in the gamma(2) subunit of AMP-activated protein kinase cause familial hypertrophic cardiomyopathy: Evidence for the central role of energy compromise in disease pathogenesis. Hum. Mol. Genet. 2001, 10, 1215-1220. [CrossRef]

141. Bolster, D.R.; Crozier, S.J.; Kimball, S.R.; Jefferson, L.S. AMP-activated protein kinase suppresses protein synthesis in rat skeletal muscle through down-regulated mammalian target of rapamycin (mTOR) signaling. J. Biol. Chem. 2002, 277, 23977-23980. [CrossRef]

142. Chan, A.Y.; Soltys, C.L.; Young, M.E.; Proud, C.G.; Dyck, J.R. Activation of AMP-activated protein kinase inhibits protein synthesis associated with hypertrophy in the cardiac myocyte. J. Biol. Chem. 2004, 279, 32771-32779. [CrossRef]

143. Zhang, C.X.; Pan, S.N.; Meng, R.S.; Peng, C.Q.; Xiong, Z.J.; Chen, B.L.; Chen, G.Q.; Yao, F.J.; Chen, Y.L.; Ma, Y.D.; et al. Metformin attenuates ventricular hypertrophy by activating the AMP-activated protein kinase-endothelial nitric oxide synthase pathway in rats. Clin. Exp. Pharmacol. Physiol. 2011, 38, 55-62. [CrossRef] [PubMed]

144. Hernández, J.S.; Barreto-Torres, G.; Kuznetsov, A.V.; Khuchua, Z.; Javadov, S. Crosstalk between AMPK activation and angiotensin II-induced hypertrophy in cardiomyocytes: The role of mitochondria. J. Cell Mol. Med. 2014, 18, 709-720. [CrossRef] [PubMed]

145. Tang, X.; Chen, X.F.; Wang, N.Y.; Wang, X.M.; Liang, S.T.; Zheng, W.; Lu, Y.B.; Zhao, X.; Hao, D.L.; Zhang, Z.Q.; et al. SIRT2 acts as a cardioprotective deacetylase in pathological cardiac hypertrophy. Circulation 2017, 136, 2051-2067. [CrossRef] [PubMed]

146. Packer, M. Longevity genes, cardiac ageing, and the pathogenesis of cardiomyopathy: Implications for understanding the effects of current and future treatments for heart failure. Eur. Heart J. 2020, 41, 3856-3861. [CrossRef]

147. Li, Y.; Zhang, D.; Kong, L.; Shi, H.; Tian, X.; Gao, L.; Liu, Y.; Wu, L.; Du, B.; Huang, Z.; et al. Aldolase promotes the development of cardiac hypertrophy by targeting AMPK signaling. Exp. Cell Res. 2018, 370, 78-86. [CrossRef] [PubMed]

148. Xu, X.; Lu, Z.; Fassett, J.; Zhang, P.; Hu, X.; Liu, X.; Kwak, D.; Li, J.; Zhu, G.; Tao, Y.; et al. Metformin protects against systolic overload-induced heart failure independent of AMP-activated protein kinase $\alpha 2$. Hypertension 2014, 63, 723-728. [CrossRef] [PubMed]

149. Sunagawa, Y.; Shimizu, K.; Katayama, A.; Funamoto, M.; Shimizu, K.; Nurmila, S.; Shimizu, S.; Miyazaki, Y.; Katanasaka, Y.; Hasegawa, K.; et al. Metformin suppresses phenylephrine-induced hypertrophic responses by inhibiting p300-HAT activity in cardiomyocytes. J. Pharmacol. Sci. 2021, 147, 169-175. [CrossRef] [PubMed]

150. Yanazume, T.; Morimoto, T.; Wada, H.; Kawamura, T.; Hasegawa, K. Biological role of p300 in cardiac myocytes. Mol. Cell Biochem. 2003, 248, 115e119. [CrossRef]

151. Mohan, M.; Al-Talabany, S.; McKinnie, A.; Mordi, I.R.; Singh, J.S.S.; Gandy, S.J.; Baig, F.; Hussain, M.S.; Bhalraam, U.; Khan, F.; et al. A randomized controlled trial of metformin on left ventricular hypertrophy in patients with coronary artery disease without diabetes: The MET-REMODEL trial. Eur. Heart J. 2019, 40, 3409-3417. [CrossRef]

152. Xiao, H.; Ma, X.; Feng, W.; Fu, Y.; Lu, Z.; Xu, M.; Shen, Q.; Zhu, Y.; Zhang, Y. Metformin attenuates cardiac fibrosis by inhibiting the TGFbeta1-Smad3 signalling pathway. Cardiovasc. Res. 2010, 87, 504-513. [CrossRef] [PubMed]

153. Wang, X.F.; Zhang, J.Y.; Li, L.; Zhao, X.Y. Beneficial effects of metformin on primary cardiomyocytes via activation of adenosine monophosphate-activated protein kinase. Chin. Med. J. 2011, 124, 1876-1884. 
154. Noppe, G.; Dufeys, C.; Buchlin, P.; Marquet, N.; Castanares-Zapatero, D.; Balteau, M.; Hermida, N.; Bouzin, C.; Esfahani, H.; Viollet, B.; et al. Reduced scar maturation and contractility lead to ex-aggerated left ventricular dilation after myocardial infarction in mice lacking AMPK $\alpha 1$. J. Mol. Cell Cardiol. 2014, 74, 32-43. [CrossRef]

155. Bai, J.; Zhang, N.; Hua, Y.; Wang, B.; Ling, L.; Ferro, A.; Xu, B. Metformin inhibits angiotensin II-induced differentiation of cardiac fibroblasts into myofibroblasts. PLoS ONE 2013, 8, e72120. [CrossRef]

156. Brings, S.; Fleming, T.; Freichel, M.; Muckenthaler, M.U.; Herzig, S.; Nawroth, P.P. Dicarbonyls and advanced glycation end-products in the development of diabetic complications and targets for intervention. Int. J. Mol. Sci. 2017, 18, 984. [CrossRef] [PubMed]

157. Jyothirmayi, G.N.; Soni, B.J.; Masurekar, M.; Lyons, M.; Regan, T.J. Effects of metformin on collagen glycation and diastolic dys-function in diabetic myocardium. J. Cardiovasc. Pharmacol. Ther. 1998, 3, 319-326. [CrossRef]

158. Kuethe, F.; Sigusch, H.H.; Bornstein, S.R.; Hilbig, K.; Kamvissi, V.; Figulla, H.R. Apoptosis in patients with dilated cardiomyopathy and diabetes: A feature of diabetic cardiomyopathy? Horm. Metab. Res. 2007, 39, 672-676. [CrossRef] [PubMed]

159. Elmadhun, N.Y.; Sabe, A.A.; Lassaletta, A.D.; Chu, L.M.; Sellke, F.W. Metformin mitigates apoptosis in ischemic myocardium. J. Surg. Res. 2014, 192, 50-58. [CrossRef]

160. Verma, S.; McNeill, J.H. Metformin improves cardiac function in isolated streptozotocin-diabetic rat hearts. Am. J. Physiol. 1994, 266, H714-H719. [CrossRef]

161. Benes, J.; Kazdova, L.; Drahota, Z.; Houstek, J.; Medrikova, D.; Kopecky, J.; Kovarova, N.; Vrbacky, M.; Sedmera, D.; Strnad, H.; et al. Effect of metformin therapy on cardiac function and survival in a volume-overload model of heart failure in rats. Clin. Sci. 2011, 121, 29-41. [CrossRef]

162. Wang, X.F.; Zhang, J.Y.; Li, L.; Zhao, X.Y.; Tao, H.L.; Zhang, L. Metformin improves cardiac function in rats via activation of AMP-activated protein kinase. Clin. Exp. Pharmacol. Physiol. 2011, 38, 94-101. [CrossRef]

163. Yin, M.; van der Horst, I.C.; van Melle, J.P.; Qian, C.; van Gilst, W.H.; Silljé, H.H.; de Boer, R.A. Metformin improves cardiac function in a nondiabetic rat model of post-MI heart failure. Am. J. Physiol. Heart Circ. Physiol. 2011, 301, H459-H468. [CrossRef]

164. Lai, Y.C.; Tabima, D.M.; Dube, J.J.; Hughan, K.S.; Vanderpool, R.R.; Goncharov, D.A.; St Croix, C.M.; Garcia-Ocaña, A.; Goncharova, E.A.; Tofovic, S.P.; et al. SIRT3-AMP-activated protein kinase activation by nitrite and metformin improves hy-perglycemia and normalizes pulmonary hypertension associated with heart failure with preserved ejection fraction. Circulation 2016, 133, 717-731. [CrossRef]

165. Slater, R.E.; Strom, J.G.; Methawasin, M.; Liss, M.; Gotthardt, M.; Sweitzer, N.; Granzier, H.L. Metformin improves diastolic function in an HFpEF-like mouse model by increasing titin compliance. J. Gen. Physiol. 2019, 151, 42-52. [CrossRef] [PubMed]

166. Borbély, A.; van der Velden, J.; Papp, Z.; Bronzwaer, J.G.; Edes, I.; Stienen, G.J.; Paulus, W.J. Cardiomyocyte stiffness in diastolic heart failure. Circulation 2005, 111, 774-781. [CrossRef] [PubMed]

167. Fang, Z.Y.; Schull-Meade, R.; Downey, M.; Prins, J.; Marwick, T.H. Determinants of subclinical diabetic heart disease. Diabetologia 2005, 48, 394-402. [CrossRef]

168. Giorda, C.B.; Cioffi, G.; de Simone, G.; Di Lenarda, A.; Faggiano, P.; Latini, R.; Lucci, D.; Maggioni, A.P.; Tarantini, L.; Velussi, M.; et al. Predictors of early-stage left ventricular dysfunction in type 2 diabetes: Results of DYDA study. Eur. J. Cardiovasc. Prev. Rehabil. 2011, 18, 415-423. [CrossRef] [PubMed]

169. Andersson, C.; Søgaard, P.; Hoffmann, S.; Hansen, P.R.; Vaag, A.; Major-Pedersen, A.; Hansen, T.F.; Bech, J.; Køber, L.; TorpPedersen, C.; et al. Metformin is associated with improved left ventricular diastolic function measured by tissue Doppler imaging in patients with diabetes. Eur. J. Endocrinol. 2010, 163, 593-599. [CrossRef]

170. Leung, M.; Wong, V.W.; Hudson, M.; Leung, D.Y. Impact of improved glycemic control on cardiac function in type 2 diabetes mellitus. Circ. Cardiovasc. Imaging 2016, 9, e003643. [CrossRef]

171. Shah, D.D.; Fonarow, G.C.; Horwich, T.B. Metformin therapy and outcomes in patients with advanced systolic heart failure and diabetes. J. Card. Fail. 2010, 16, 200-206. [CrossRef]

172. Gu, J.; Yin, Z.F.; Zhang, J.F.; Wang, C.Q. Association between long-term prescription of metformin and the progression of heart failure with preserved ejection fraction in patients with type 2 diabetes mellitus and hypertension. Int. J. Cardiol. 2020, 306, 140-145. [CrossRef]

173. Wong, A.K.; Symon, R.; AlZadjali, M.A.; Ang, D.S.; Ogston, S.; Choy, A.; Petrie, J.R.; Struthers, A.D.; Lang, C.C. The effect of metformin on insulin resistance and exercise parameters in patients with heart failure. Eur. J. Heart Fail. 2012, 14, 1303-1310. [CrossRef] [PubMed]

174. Lexis, C.P.; van der Horst, I.C.; Lipsic, E.; Wieringa, W.G.; de Boer, R.A.; van den Heuvel, A.F.; van der Werf, H.W.; Schurer, R.A.; Pundziute, G.; Tan, E.S.; et al. Effect of metformin on left ventricular function after acute myocardial infarction in patients without diabetes: The GIPS-III randomized clinical trial. JAMA 2014, 311, 1526-1535. [CrossRef] [PubMed]

175. Al Ali, L.; Hartman, M.T.; Lexis, C.P.; Hummel, Y.M.; Lipsic, E.; van Melle, J.P.; van Veldhuisen, D.J.; Voors, A.A.; van der Horst, I.C.; van der Harst, P. The effect of metformin on diastolic function in patients presenting with ST-elevation myocardial infarction. PLoS ONE 2016, 11, e0168340. [CrossRef]

176. Hartman, M.H.T.; Prins, J.K.B.; Schurer, R.A.J.; Lipsic, E.; Lexis, C.P.H.; van der Horst- Schrivers, A.N.A.; van Veldhuisen, D.J.; van der Horst, I.C.C.; van der Harst, P. Two-year follow-up of 4 months metformin treatment vs. placebo in ST-elevation myocardial infarction: Data from the GIPS-III RCT. Clin. Res. Cardiol. 2017, 106, 939-946. [CrossRef] [PubMed] 
177. Dludla, P.V.; Nyambuya, T.M.; Johnson, R.; Silvestri, S.; Orlando, P.; Mazibuko- Mbeje, S.E.; Gabuza, K.B.; Mxinwa, V.; Mokgalaboni, K.; Tiano, L.; et al. Metformin and heart failure-related outcomes in patients with or without diabetes: A systematic review of randomized controlled trials. Heart Fail. Rev. 2021, 26, 1437-1445. [CrossRef]

178. Ladeiras-Lopes, R.; Sampaio, F.; Leite, S.; Santos-Ferreira, D.; Vilela, E.; Leite-Moreira, A.; Bettencourt, N.; Gama, V.; Braga, P.; Fon-tes-Carvalho, R. Metformin in non-diabetic patients with metabolic syndrome and diastolic dysfunction: The MET-DIME randomized trial. Endocrine 2021, 72, 699-710. [CrossRef]

179. Evans, J.M.; Doney, A.S.; AlZadjali, M.A.; Ogston, S.A.; Petrie, J.R.; Morris, A.D.; Struthers, A.D.; Wong, A.K.; Lang, C.C. Effect of Metformin on mortality in patients with heart failure and type 2 diabetes mellitus. Am. J. Cardiol. 2010, 106, 1006-1010. [CrossRef]

180. Andersson, C.; Olesen, J.B.; Hansen, P.R.; Weeke, P.; Norgaard, M.L.; Jø rgensen, C.H.; Lange, T.; Abildstrø m, S.Z.; Schramm, T.K.; Vaag, A.; et al. Metformin treatment is associated with a low risk of mortality in diabetic patients with heart failure: A retrospective nationwide cohort study. Diabetologia 2010, 53, 2546-2553. [CrossRef] [PubMed]

181. Roumie, C.L.; Min, J.Y.; D’Agostino McGowan, L.; Presley, C.; Grijalva, C.G.; Hackstadt, A.J.; Hung, A.M.; Greevy, R.A.; Elasy, T.; Griffin, M.R. Comparative Safety of Sulfonylurea and Metformin Monotherapy on the Risk of Heart Failure: A Cohort Study. J. Am. Heart Assoc. 2017, 6, e005379. [CrossRef] [PubMed]

182. MacDonald, M.R.; Eurich, D.T.; Majumdar, S.R.; Lewsey, J.D.; Bhagra, S.; Jhund, P.S.; Petrie, M.C.; McMurray, J.J.; Petrie, J.R.; McAlister, F.A. Treatment of type 2 diabetes and outcomes in patients with heart failure: A nested case-control study from the U.K. General Practice Research Database. Diabetes Care 2010, 33, 1213-1218. [CrossRef]

183. Roussel, R.; Travert, F.; Pasquet, B.; Wilson, P.W.; Smith, S.C., Jr.; Goto, S.; Ravaud, P.; Marre, M.; Porath, A.; Bhatt, D.L.; et al. Reduction of Atherothrombosis for Continued Health (REACH) Registry Investigators. Metformin use and mortality among patients with diabetes and atherothrombosis. Arch. Intern. Med. 2010, 170, 1892-1899. [CrossRef]

184. Aguilar, D.; Chan, W.; Bozkurt, B.; Ramasubbu, K.; Deswal, A. Metformin use and mortality in ambulatory patients with diabetes and heart failure. Circ. Heart Fail. 2011, 4, 53-58. [CrossRef]

185. Fung, C.S.; Wan, E.Y.; Wong, C.K.; Jiao, F.; Chan, A.K. Effect of metformin monotherapy on cardiovascular diseases and mortality: A retrospective cohort study on Chinese type 2 diabetes mellitus patients. Cardiovasc. Diabetol. 2015, 14, 137. [CrossRef] [PubMed]

186. Herrera Comoglio, R.; Vidal Guitart, X. Cardiovascular events and mortality among type 2 diabetes mellitus patients newly prescribed first-line blood glucose-lowering drugs monotherapies: A population-based cohort study in the Catalan electronic medical record database, SIDIAP, 2010-2015. Prim. Care Diabetes 2021, 15, 323-331. [CrossRef]

187. He, S.; Qian, X.; Chen, Y.; Shen, X.; Zhang, B.; Chen, X.; Xu, X.; Li, G. Risk of Death and Heart Failure among Patients with Type 2 Diabetes Treated by Metformin and Nonmetformin Monotherapy: A Real-World Study. J. Diabetes Res. 2021, $2021,5534387$. [CrossRef] [PubMed]

188. Romero, S.P.; Andrey, J.L.; Garcia-Egido, A.; Escobar, M.A.; Perez, V.; Corzo, R.; Garcia- Domiguez, G.J.; Gomez, F. Metformin therapy and prognosis of patients with heart failure and new-onset diabetes mellitus. A propensity-matched study in the community. Int. J. Cardiol. 2013, 166, 404-412. [CrossRef]

189. Lamanna, C.; Monami, M.; Marchionni, N.; Mannucci, E. Effect of metformin on cardiovascular events and mortality: A me-ta-analysis of randomized clinical trials. Diabetes Obes. Metab. 2011, 13, 221-228. [CrossRef] [PubMed]

190. Bolen, S.; Tseng, E.; Hutfless, S.; Segal, J.B.; Suarez-Cuervo, C.; Berger, Z.; Wilson, L.M.; Chu, Y.; Iyoha, E.; Maruthur, N.M. Diabetes Medications for Adults with Type 2 Diabetes: An Update; 2016 Apr. Report No.: 16-EHC013-EF; Agency for Healthcare Research and Quality: Rockville, MD, USA, 2016.

191. Crowley, M.J.; Diamantidis, C.J.; McDuffie, J.R.; Cameron, C.B.; Stanifer, J.W.; Mock, C.K.; Wang, X.; Tang, S.; Nagi, A.; Kosinski, A.S.; et al. Clinical outcomes of metformin use in populations with chronic kidney disease, congestive heart failure, or chronic liver disease: A systematic review. Ann. Intern. Med. 2017, 166, 191-200. [CrossRef] [PubMed]

192. Han, Y.; Xie, H.; Liu, Y.; Gao, P.; Yang, X.; Shen, Z. Effect of metformin on all-cause and cardiovascular mortality in patients with coronary artery diseases: A systematic review and an updated meta-analysis. Cardiovasc. Diabetol. 2019, 18, 96. [CrossRef]

193. Fácila, L.; Fabregat-Andrés, Ó.; Bertomeu, V.; Navarro, J.P.; Miñana, G.; García-Blas, S.; Valero, E.; Morell, S.; Sanchis, J.; Núñez, J. Met-formin and risk of long-term mortality following an admission for acute heart failure. J. Cardiovasc. Med. 2017, 18, 69-73. [CrossRef]

194. Wang, J.; Lu, Y.; Min, X.; Yuan, T.; Wei, J.; Cai, Z. The Association Between Metformin Treatment and Outcomes in Type 2 Diabetes Mellitus Patients With Heart Failure With Preserved Ejection Fraction: A Retrospective Study. Front. Cardiovasc. Med. 2021, 8, 648212. [CrossRef]

195. Halabi, A.; Sen, J.; Huynh, Q.; Marwick, T.H. Metformin treatment in heart failure with preserved ejection fraction: A systematic review and meta-regression analysis. Cardiovasc. Diabetol. 2020, 19, 124. [CrossRef] [PubMed]

196. Eurich, D.T.; Weir, D.L.; Majumdar, S.R.; Tsuyuki, R.T.; Johnson, J.A.; Tjosvold, L.; Vanderloo, S.E.; McAlister, F.A. Comparative safety and effectiveness of metformin in patients with diabetes mellitus and heart failure: Systematic review of observational studies involving 34,000 patients. Circ. Heart Fail. 2013, 6, 395-402. [CrossRef]

197. Giordano, M.; Ciarambino, T.; Castellino, P.; Malatino, L.; Cataliotti, A.; Rinaldi, L.; Paolisso, G. Adinolfi LE Seasonal variations of hyponatremia in the emergency department: Age-related changes. Am. J. Emerg. Med. 2017, 35, 749-752. [CrossRef] [PubMed]

198. Boussageon, R.; Supper, I.; Bejan-Angoulvant, T.; Kellou, N.; Cucherat, M.; Boissel, J.P.; Kassai, B.; Moreau, A.; Gueyffier, F.; Cornu, C. Reappraisal of metformin efficacy in the treatment of type 2 diabetes: A meta-analysis of randomised controlled trials. PLoS Med. 2012, 9, e1001204. [CrossRef] 
199. Griffin, S.J.; Leaver, J.K.; Irving, G.J. Impact of metformin on cardiovascular disease: A meta-analysis of randomised trials among people with type 2 diabetes. Diabetologia 2017, 60, 1620-1629. [CrossRef]

200. Palmer, S.C.; Mavridis, D.; Nicolucci, A.; Johnson, D.W.; Tonelli, M.; Craig, J.C.; Maggo, J.; Gray, V.; De Berardis, G.; Ruospo, M.; et al. Comparison of clinical outcomes and adverse events associated with glucose-lowering drugs in patients with type 2 diabetes: A meta-analysis. JAMA 2016, 316, 313-324. [CrossRef]

201. Rao, A.D.; Kuhadiya, N.; Reynolds, K.; Fonseca, V.A. Is the combination of sulfonylureas and metformin associated with an in-creased risk of cardiovascular disease or all-cause mortality? A meta-analysis of observational studies. Diabetes Care 2008, 31, 1672-1678. [CrossRef] [PubMed]

202. Hariyanto, T.I.; Kurniawan, A. Metformin use is associated with reduced mortality rate from coronavirus disease 2019 (COVID-19) infection. Obes Med. 2020, 19, 100290. [CrossRef] [PubMed]

203. Luo, P.; Qiu, L.; Liu, Y.; Liu, X.L.; Zheng, J.L.; Xue, H.Y.; Liu, W.H.; Liu, D.; Li, J. Metformin treatment was associated with decreased mortality in COVID-19 patients with diabetes in a retrospective analysis. Am. J. Trop. Med. Hyg. 2020, 103, 69-72. [CrossRef]

204. Kow, C.S.; Hasan, S.S. Mortality risk with preadmission metformin use in patients with COVID-19 and diabetes: A meta-analysis. J. Med. Virol. 2021, 93, 695-697. [CrossRef]

205. Richardson, T.L., Jr.; Hackstadt, A.J.; Hung, A.M.; Greevy, R.A.; Grijalva, C.G.; Griffin, M.R.; Elasy, T.A.; Roumie, C.L. Hospitalization for heart failure among patients with diabetes mellitus and reduced kidney function treated with metformin versus sulfonylureas: A retrospective cohort study. J. Am. Heart Assoc. 2021, 10, e019211. [CrossRef]

206. Weir, D.L.; Abrahamowicz, M.; Beauchamp, M.E.; Eurich, D.T. Acute vs cumulative benefits of metformin use in patients with type 2 diabetes and heart failure. Diabetes Obes. Metab. 2018, 20, 2653-2660. [CrossRef]

207. Tseng, C.H. Metformin use is associated with a lower risk of hospitalization for heart failure in patients with type 2 diabetes mellitus: A retrospective cohort analysis. J. Am. Heart Assoc. 2019, 8, e011640. [CrossRef]

208. Nichols, G.A.; Koro, C.E.; Gullion, C.M.; Ephross, S.A.; Brown, J.B. The incidence of congestive heart failure associated with antidi-abetic therapies. Diabetes Metab. Res. Rev. 2005, 21, 51-57. [CrossRef] [PubMed]

209. Pantalone, K.M.; Kattan, M.W.; Yu, C.; Wells, B.J.; Arrigain, S.; Jain, A.; Atreja, A.; Zimmerman, R.S. The risk of developing coronary artery disease or congestive heart failure, and overall mortality, in type 2 diabetic patients receiving rosiglitazone, pioglitazone, metformin, or sulfonylureas: A retrospective analysis. Acta Diabetol. 2009, 46, 145-154. [CrossRef]

210. McAlister, F.A.; Eurich, D.T.; Majumdar, S.R.; Johnson, J.A. The risk of heart failure in patients with type 2 diabetes treated with oral agent monotherapy. Eur. J. Heart Fail. 2008, 10, 703-708. [CrossRef]

211. Zhu, J.; Yu, X.; Zheng, Y.; Li, J.; Wang, Y.; Lin, Y.; He, Z.; Zhao, W.; Chen, C.; Qiu, K.; et al. Association of glucose-lowering medications with cardiovascular outcomes: An umbrella review and evidence map. Lancet Diabetes Endocrinol. 2020, 8, 192-205. [CrossRef]

212. Fralick, M.; Schneeweiss, S.; Redelmeier, D.A.; Razak, F.; Gomes, T.; Patorno, E. Comparative effectiveness and safety of sodi-umglucose cotransporter- 2 inhibitors versus metformin in patients with type 2 diabetes: An observational study using data from routine care. Diabetes Obes. Metab. 2021, 23, 2320-2328. [CrossRef]

213. Rosenstock, J.; Chuck, L.; González-Ortiz, M.; Merton, K.; Craig, J.; Capuano, G.; Qiu, R. Initial combination therapy with canagliflozin plus metformin versus each component as monotherapy for drug-naïve type 2 diabetes. Diabetes Care 2016, 39, 353-362. [CrossRef]

214. Hedrington, M.S.; Davis, S.N. The role of empagliflozin in the management of type 2 diabetes by patient profile. Clin. Risk Manag. 2015, 11, 739-749.

215. Salvatore, T.; Pafundi, P.C.; Morgillo, F.; Di Liello, R.; Galiero, R.; Nevola, R.; Marfella, R.; Monaco, L.; Rinaldi, L.; Adinolfi, L.E.; et al. Metformin: An old drug against old age and associated morbidities. Diabetes Res. Clin. Pract. 2020, $160,108025$. [CrossRef] [PubMed]

216. Morgillo, F.; Sasso, F.C.; Della Corte, C.M.; Festino, L.; Manzo, A.; Martinelli, E.; Troiani, T.; Capuano, A.; Ciardiello, F. Metformin in lung cancer: Rationale for a combination therapy. Expert Opin. Investig. Drugs. 2013, 22, 1401-1409. [CrossRef]

217. Morgillo, F.; Fasano, M.; Della Corte, C.M.; Sasso, F.C.; Papaccio, F.; Viscardi, G.; Esposito, G.; Di Liello, R.; Normanno, N.; Capuano, A.; et al. Results of the safety run-in part of the METAL (METformin in Advanced Lung cancer) study: A multicentre, open-label phase I-II study of metformin with erlotinib in second-line therapy of patients with stage IV non-small-cell lung cancer. ESMO Open 2017, 2, e000132. [CrossRef] [PubMed]

218. Wiggers, H.; Køber, L.; Gislason, G.; Schou, M.; Poulsen, M.K.; Vraa, S.; Nielsen, O.W.; Bruun, N.E.; Nørrelund, H.; Hollingdal, M.; et al. The DANish randomized, double-blind, placebo controlled trial in patients with chronic HEART failure (DANHEART): A $2 \times 2$ factorial trial of hydralazine-isosorbide dinitrate in patients with chronic heart failure $(\mathrm{H}-\mathrm{HeFT})$ and metformin in patients with chronic heart failure and diabetes or prediabetes (Met-HeFT). Am. Heart J. 2021, 231, 137-146. [CrossRef] [PubMed]

219. Griffin, S.J.; Bethel, M.A.; Holman, R.R.; Khunti, K.; Wareham, N.; Brierley, G.; Davies, M.; Dymond, A.; Eichenberger, R.; Evans, P.; et al. Metformin in non-diabetic hyperglycaemia: The GLINT feasibility RCT. Health Technol. Assess. 2018, 22, 1-64. [CrossRef] 